доктор історичних наук, дочент. завідувач кафедри історії Украӥни

Дрогобииького державного педагогічного університету імені Івана Франка (Україна, Дрогобич) vilnickiy@gmail.com

Микола ПАНТЮК, orcid.org/0000-0002-4969-052X доктор педагогічних наук, професор кафедри загальної педагогіки та дошкільної освіти, проректор з наукової роботи Дрогобицького державного педагогічного університету імені Івана Франка, (Украӥна, Дрогобич) pantyuk.m@bigmir.net

\title{
ДІЯЛЬНІСТЬ СТАРШИНСЬКОЇ ШКОЛИ УПА ІМЕНІ ПОЛК. Є. КОНОВАЛЬЦЯ НА КОЛОМИЙЩИНІ (ІЗ ОСОБИСТИХ ЗІЗНАННЬ ФЕДОРА СТЕФАНОВИЧА- «КРОПИВИ») ${ }^{1}$
}

У статті публікується протокол допиту організатора та першого керівника старшинської школи УПА імені полк. С. Коновальия на Гуиульщині Федора Стефановича-«Кропиви», щео розкриває питання функціонування стариинських і підстариинських шкіл УПА у ВО-4 «Говерля». Простежуються особливості вишкільної діяльності: викладацькі кадри, програли, продуктивність роботи. Встановлено, що, зважаючи на постійні бойові дії і втрати особового та керівного складу, проблема підготовки професійних кадрів залишалася актуальною.

Ключові слова: Федір Стефанович, ВО-4 «Говерля», старшинські і підстаршинські школи, УПА.

Vasyl ILNYTSKYI, PhD hab. (History), Associate Professor, Head of Department of Ukraine's History of Drohobych Ivan Franko State Pedagogical University (Ukraine,Drohobych) vilnickiy@gmail.com

Mykola PANTIUK, PhD hab. (Education), Professor of Department of General Pedagogy and Preschool Education, Prorector for Research of Drohobych Ivan Franko State Pedagogical University, (Ukraine,Drohobych) pantyuk.m@bigmir.net

\section{ACTIVITIES OF COLONEL E. KONOVALETS' SERGEANTS SCHOOL OF THE UPA IN KOLOMYIA LAND (FROM THE PERSONAL EVIDENCE OF COLONEL FEDIR STEPANOVYCH ALIAS «KROPYVA»)}

For an unbiased interpretation of the history of the Ukrainian people's struggle for independence it is necessary to conduct versatile studies on the activity of Ukrainian liberation movement, particularly, on its personnel structure. Cadres play the most important role in any organization. Consequently, the clarification of the peculiarities and possibilities of their preparation makes up an important scientific problem. The article provides the protocol of the interrogation of colonel Fedir Stepanovych, whose nom de guerre was "Kropyva» ("the nettle») and who was the organizer and the first head of Colonel E. Konovalets' Officer School of the UPA in the Hutsul region. It should be underlined that the aforementioned document is an important source for a complex research of Ukrainian liberation movement in general and the peculiarities of preparation of master sergeants (starshyn) and staff sergeants (pidstarsshyn) specifically. The published protocol clarifies the question of functioning of master and staff sergeants schools of the UPA in MD-4 «Hoverlia». F. Stepanovych' own evidence describes the officer school's disposition place, strength, the names of administrative staff, programs, productivity of work. Besides, it gives the general information on the administrative staff of the OUN and UPA in Stanislaviv land.

There is no separate complex research on the functioning of centres of preparation of commanding and rankand-file staff of the UPA's MD-4 «Hoverlia». That is the reason why this article purposes to provide the available

\footnotetext{
${ }^{1}$ Публікація містить результати досліджень, проведених при грантовій підтримці Держаного фонду фундаментальних досліджень за конкурсним проектом договір Ф77/80-2017 від 31.08.2017 р.
} 
information on the peculiarities of functioning of master sergeants (starshyn) and staff sergeants (pidstarsshyn) schools in MD-4 «Hoverlia».

In the territory of Karpatskyi Krai (the Carpathian area of OUN) the shortage of master sergeants (starshyn) and staff sergeants (pidstarsshyn) cadres was acute. This problem was solved by both enrolling of persons who served in the armies of other states and by the independent preparation of such. For that purpose separate training courses were organized in accordance with independently developed programs to prepare commanding and rankand-file staff. On the whole, master and staff sergeants training lasted from one to four months. Their instructors were those who had previous military experience. In addition, the UPA sergeants schools which absorbed the skilled staff of instructors who began intense training differed qualitatively from the rest. After the decision to organize military preparation for a number of OUN members the OUN leadership took to carrying it out. It is found out that there functioned 14 master and staff sergeants schools in the Karpatskyi Krai territory

Hence, for the Ukrainian insurgents, combating for the restoration of their own state, the provision of their structures with professional cadres was a priority task. This question was solved by organization of their own training courses, under the supervision of skilled insurgents who had earlier participated in military service in the armies of other states and received direct fighting experience. Almost ten years of the Ukrainian liberation movement's opposition to the Soviet punitive system became a bright acknowledgement of the effective work of training structures in MD-4 «Hoverlia».

Keywords: Fedir Stepanovych, MD-4 «Hoverlia», master sergeants (starshyny) and staff sergeants (pidstarsshyny) schools, UPA.

Василий ИЛЬНИЦКИЙ,

доктор исторических наук, дочент заведующий кафедры истории Украины Дрогобычского государственного педагогического университета имени Ивана Франко (Украина, Дрогобич) vilnickiy@gmail.com

Николай ПАНТЮК,

доктор педагогических наук, профессор кафедры общей педагогики и дошкольного образования, проректор по научной работе Дрогобычского государственного педагогического университета имени Ивана Франко, (Украина, Дрогобыч)pantyuk.m@bigmir.net

\section{ДЕЯТЕЛЬНОСТЬ СТАРШИНСКОЙ ШКОЛЫ УПА ИМЕНИ ПОЛК. Е. КОНОВАЛЬЦЯ НА КОЛОМЫЙЩИНЕ (С ЛИЧНОГО ПРИЗНАНИЯ ФЕДОРА СТЕФАНОВИЧА-«КРАПИВЫ»)}

В статье публикуется протокол допроса организатора и первого руководителя старшинской школьл УПА имени полк. Е. Коновальиа на Гуиульщчине Федора Стефановича-«Крапивы», раскрывающий вопросы функционирования офииерских и подстариинской школ УПА в ВО-4 «Говерла». Прослеживаются особенности вышкильной деятельности: преподавательские кадры, программы, производительность работьл. Установлено, что, несмотря на постоянные боевые действия и потери личного и руководящего состава, проблема подготовки профессиональных кадров оставалась актуальной.

Ключевые слова: Федор Стефанович, ВО-4 «Говерла», стариинские и подстариинские школь,, УПА.

Постановка проблеми. Для об’єктивного висвітлення історії боротьби українського народу необхідне різностороннє вивчення діяльності визвольного руху, зокрема і його кадрового складу. У діяльності будь-якої структури кадри відіграють найважливішу роль. Саме тому з'ясування особливостей та можливостей їхньої підготовки становить важливу наукову проблему.

Аналіз джерел та останніх досліджень. Окреме комплексне дослідження, у якому б розглядалися питання функціонування центрів підготовки командних і рядових кадрів відділів УПА ВО-4 «Говерля», відсутнє. Безпосередньо питання функціонування старшинських і підстаршинських шкіл УПА вивчав I. Патриляк (Патриляк, 2004a; Патриляк, 2004b). Окремі аспекти проблеми знайшли відображення в узагальнювальних працях з історії українського визвольного руху А. Кентія (Кентій, 1999), Ю. Киричука (Киричук, 2003), А. Русначенка (Русначенко, 2002). Деякі аспекти функціонування та військового вишколу старшинських і підстаршинських кадрів у Буковинській окрузі розглядав автор цієї розвідки (Ільницький, 2016: 60-68). Саме тому мета статті - доповнити наявну 
інформацію про особливості функціонування старшинських і підстаршинських шкіл у ВО-4 «Говерля».

Виклад основного матеріалу. У будь-якій армії професійні кадри можуть вирішити не лише долю окремого бою, але й хід цілої війни. УПА, зокрема на території Карпатського краю, відчувала нестачу офіцерських (старшинських) і сержантських (підстаршинських) кадрів. Цю проблему розв'язували як залученням осіб, які служили в арміях інших держав, так і самостійною підготовкою. Організовувалися власні вишкільні курси за самостійно розробленими програмами, щоб підготувати командний і рядовий склад. Загалом старшинські та підстаршинські вишколи тривали від одного місяця до чотирьох. Інструкторами на них були ті, хто мав попередній військовий досвід. При цьому якісно відрізнялися старшинські школи УПА, до яких влився досвідчений інструкторський склад та розпочав інтенсивну підготовку (Літопис УПА, 1992: 37). Після

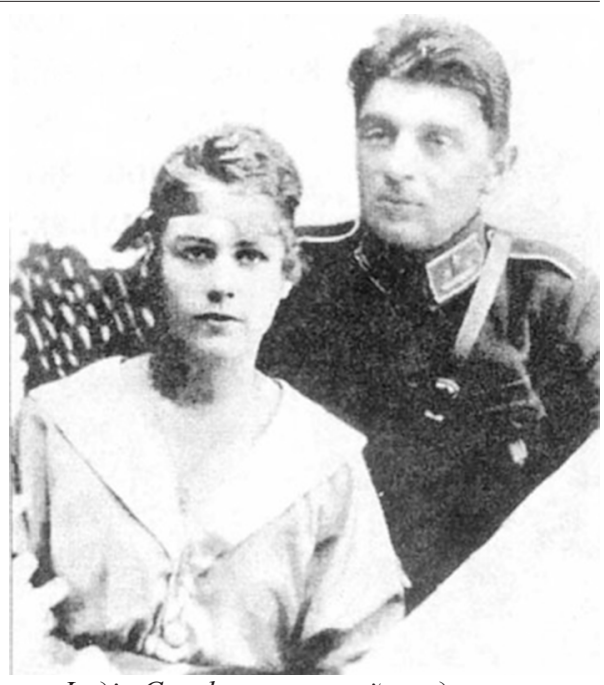

Федір Стефанович та його дружина Вікторія прийняття рішення організувати для низки членів ОУН військовий вишкіл Провід ОУН почав його практичну реалізацію. До речі, для ефективного навчання необхідно було мати і відповідну фахову літературу. Знову ж таки, цю проблему розв'язували за рахунок захоплених чи здобутих вишкільних видань у ворожих регулярних армій, що давало змогу використовувати іiі не лише для підготовки, але й знайомитися з тактикою супротивника, готувати контрзаходи.

На теренах Карпатського краю існували 14 старшинських і підстаршинських шкіл 1) «Чорні чорти» (липень - листопад 1943 р., біля с. Космач, командир - Ілько Рачок-«Липей», (Коломийська округа)); 2) «Гайдамаки-1» (липень - листопад 1943 р.) та 3) «Гайдамаки-2» (грудень 1943 - лютий 1944 р.) обидві школи дислокувалися біля г. Магура та с. Липа, командир - Степан Фрасуляк-«Хмель» (Калуська округа); 4) «Крилаті» (квітень - липень 1944 р.), дислокувалася біля с. Сприня - Звір - Недільна, командир школи Іван Гудзоватий-«Петрович» (Самбірська округа); 5) «Олені-1» (функціонувала березень - липень 1944 р.) та 6) «Олені-2» (функціонувала липень - жовтень 1944 р.), дислокувалися біля г. Магура, с. Липа Долинського р-ну і с. Бряза, школи Степан Фрасуляк-«Хмель», Федір Польовий-«Поль» (Калуська округа); 7) старшинська школа ім. Коновальця (травень - серпень 1944 р.), дислокувалася у с. Брустури, командир - Федір Стефанович-«Кропива» (Коломийська округа); 8) «Беркути» (серпень - вересень 1944 р.), дислокувалася біля г. Малиновище, командир - «Чмелик» (Станиславівська округа); 9) школа кадрів ОУН «Тигри» (травень - серпень 1944 р.), дислокувалася у Долинському р-ні, командири Михайло Федоришин-«Стефаник», Петро Федун-«Волянський» (Калуська округа); 10) «Кривоніс-1» (липень?серпень - жовтень 1943 р.), дислокувалася у Славському р-ні, командир - Омелян Польовий-«Шахай» (Стрийська округа); 11) «Кривоніс-2» (липень?серпень - листопад 1943 р.), дислокувалася біля с. Недільна Стрілківського р-ну, командир - Антін Шкітак-«Омелян» (Самбірська округа); 12) підстаршинська школа Групи «Гуцульщина» (серпень - вересень 1944 р.), дислокувалася біля с. Голови Верховинського р-ну, командир «Степовий» (Коломийська округа); 13) підстаршинська школа Групи «Гуцульщина» (функціонувала січень - лютий 1945 р.), дислокувалася біля с. Космач, командир - «Степовий» (Коломийська округа); 14) підстаршинська школа Буковини (грудень 1944 - лютий 1945 р.), дислокувалася біля с. Конятин, командир - Назарій Данилюк-«Перебийніс» (Буковинська округа).

Перші відомі вишкільні табори почали створюватися у травні - червні 1943 р. (вишкільні курені: «Гайдамаки» (до 300 бійців) і «Чорні чорти» (1943) (до 300 бійців). Саме ця робота дала змогу у листопаді 1943 р. направити із куреня «Гайдамаки» дві сотні у Тернопільську і Львівську області, а на базі третьої сформувати другий склад куреня до 300 бійців. У листопаді 1943 р. курінь «Чорні чорти» розділили на дві частини: одна пішла у Чорний ліс, друга - залишилася на місці. У Дрогобицькій області в 1943 р. діяли вишкільні курені у Стрийській окрузі - «Криво- 
ніс-1» (2 сотні по 70 бійців, у жовтні 1943 р. розпався і частина перейшла у Калуську округу), у Самбірській окрузі - курінь «Кривоніс-2» (2 сотні по 90 бійців, у листопаді 1943 р. зазнав серйозних втрат біля с. Недільна у бою з німцями). У січні 1944 р. крайовий провід юнацтва Західноукраїнських земель (далі - ЗУЗ) звернувся до штабу УПА-Захід, щоб зорганізувати для юнацтва окремий військовий вишкіл. У цей час в штабі планувалося створити старшинські школи (далі СШ) УПА, і цю пропозицію було реалізовано. Юнацтво ОУН направило до школи найкращих членів із повною середньою освітою, які прискорили процес мобілізації юнаків до старшинських шкіл УПА (Чижевський, 1948: 40).

На терені ВО-4 «Говерля» 1 березня 1944 р. створили СШ «Олені», яка готувала старшин і підстаршин УПА. Школа базувалася біля г. Магура на межі сучасних Сколівського і Долинського районів Львівської та Івано-Франківської областей. Вона складалася із трьох сотень курсантів (дві сотні курсантів вишколювали на старшин, а третя - на підстаршин). Дві старшинські сотні очолювали (02.1944) Михайло Гальо-«Коник»² та «Чмелик» ${ }^{3}$ і однією сотнею підстаршин керував командир Микола Твердохліб-«Грім» ${ }^{4}$ (одночасно виконував обов’язки писаря старшинської школи «Олені-1»). Від УПА-Захід куратором організації СШ «Олені» став В. Чижевський-«Демид». До речі, підготовку до організації школи розпочали в січні 1944 р. із будівництва бійцями сотні «Чмелика» бараків для майбутніх курсантів біля гори Магура. Інструкторами були М. Твердохліб-«Грім», М. Гальо-«Коник», «Чмелик» та інші. Також були два лікарі (євреї). У ході навчання долучилися до вишколу інструктори УПА з Волині. Серед них: 1) сотник Василь Брилевський-«Боровий» ${ }^{5}$; 2) поручник Федір Польовий-«Поль» ${ }^{6}$; 3) Іван Мельниченко-«Дніпровий» ${ }^{7}$; ${ }^{2}$ Гальо Михайло («Коник»; 3.10.1914, с. Посада Хирівська Старосамбірського р-ну Львівської обл. - 7.01.1946, м. Бірча, Польща). Член ОУН (1935). Вояк куреня «Нахтігаль» (1941) та 201 батальйону «Шуцманшафт» (12.1941 - 12.1942). Стрілець, ройовий, чотовий в курені УНС «Гайдамаки». Інструктор і командир сотні в старшинській школі «Олені» $(03$ - 10.1944). Надрайоновий оргмоб Перемищини (від 03.1945). Заступник командира ТВ-26 «Лемко» ВО-6 «Сян» $\mathrm{i}$ командир Перемиського куреня УПА (від 11.1945). Хорунжий (1944), поручник (15.04.1945), майор і підполковник УПА (посмертно).

3 «Чмелик» (1910?, м. Львів - 20.04.1945, с. Снідавка Косівського р-ну Івано-Франківської обл.). Закінчив гімназію м. Львів. Вояк Легіону (1941) та 201 батальйону «Шуцманшафт» (12.1941 - 12.1942). Командир вишкільного куреня УНС «Кривоніс І» на Стрийщині і командир сотні, відтак сотенний в курені УНС «Гайдамаки» в Долинському р-ні (1943 - 1944). Інструктор і командир сотні у старшинській школі «Олені І» (02 - 06.1944), командир підстаршинської школи «Беркути» у ВО «Говерля» (ІІ пол. 1944). Член Штабу ТВ-21 «Гуцульщина». Булавний, хорунжий (наказ $2 / 44$ від 26.01.1944), поручник УПА.

${ }^{4}$ Твердохліб Микола Дмитрович («Грім», «Музика», «Петро», «Північ», «ОР-4», «24», «311», «401», «090»; (1910 (або 1914 р.), с. Петрилів Тлумацького р-ну Івано-Франківської обл. - 17.05.1954 р., біля с. Зелена Надвірнянського р-ну Івано-Франківської обл.). Освіта середня. Закінчив гімназію, відтак торгівельну школу м. Станіслав. Закінчив школу підхорунжих Польської армії. Член ОУН з 1930-х рр. Працював у Станиславівській крамниці металевих виробів. Провідник ОУН по м. Івано-Франківськ (1938). Перебував на еміграції, вчився у абверівській школі у м. Криниця Польща (1939-1941). Одружений із Ольгою Герасимович (літо 1941). Член Станіславівського обласного проводу ОУН (1941 - 1945). Інструктор і командир сотні в старшинській школі «Олені-1» (від 03.1944 р.), командир ВО-4 «Говерля» (07.1944 - 04.1954). Військовий референт Карпатського крайового проводу ОУН (13.12.1944 - 05.1954), організаційний референт (1947 - 06.1949), референт СБ (06.1949 - 05.1954), в.о. крайового провідника ОУН КК (поч. 1947, 1953 - 05.1954). Нагороджений Бронзовим хрестом бойової заслуги. Сотник (ч. 2/45 від 27.04.1945), майора УПА (ч. 1 від 15.02.1946). Загинув в криївці разом 3 дружиною. Фігурант АС «Верховинці», «Петлюрівці».

5 Брилевський Василь («Боровий», «Босий»; 1915(?), с. Середпільці Радехівського р-ну Львівської обл. - 19.06.1945, с. Кліщівка Рогатинського р-ну Івано-Франківської обл.). Чотовий у батальйоні «Нахтігаль», відтак у 201 батальйоні шуцманшафт. Заарештований гестапо (01.1943), увязнений у львівській тюрмі, втік. Перейшов у відділи УПА (Волинь). Командир загону (куреня) імені Хмельницького ВО 1 «Заграва» УПА-«Північ». Інструктор старшинських і підстаршинських шкіл. Начальник 3 вишкільного відділу крайового військового штабу УПА-«Захід» (01.1944). Перевів інструкторський склад СШ «Лісові чорти» з УПА-«Північ» до СШ «Олені» (Долинщина) УПА-«Захід». Поручник, сотник, майор УПА. Нагороджений Срібним хрестом бойової заслуги 2 кл.

${ }^{6}$ Польовий Федір («Поль»; ?, Волинь - 15.10.1944, біля с. Липа Долинського р-ну Івано-Франківської обл.). Старшина польської армії, член ОУН, потім ОУН (м). Командир підстаршинської школи УПА на Волині (літо 1943), начальник вишкільного відділу КВШ УПА і КВШ УПА-Північ (08.1943 - поч. 1944), командир старшинської школи «Лісові чорти» на Волині (10.1943 - 02.1944), старшинської школи «Олені» в Карпатах (04.1944 - 10.1944). Нагороджений Золотим хрестом бойової заслуги II кл. (25.04.1945) та Срібним хрестом заслуги (11.10.1952). Хорунжий, поручник (26.01.1944), сотник (1.10.1944), майор УПА (посмертно).

${ }^{7}$ Мельниченко Іван Лукич («Дніпровий», «Степовий»1920, с. Ротичі Чорнобильського р-ну Київської обл. - ?). Навчався у середній школі с. Горностайпіль Чорнобильського р-ну Київської обл. (1927 - 1937). Поступив у Київський лісотехнічний інститут (1937). Після першого року навчання поступив у Ленінградську військовотранспортну академіюЧервоної арміїі ім. Кагановича (1938 - 05.1941). 05.1941 відправлений у Західну Білорусь для виконання спеціального 
4) Микола Симоненко-«Береза»; 5) Андрій Максименко (Тарасенко)-«Степовий» ${ }^{9}$; 6) Олександр Бондаренко-«Бондаренко», «Гамалія» ${ }^{10}$; 7) А. Фінтіктістов-«Крутий» ${ }^{11}$ (С. Федорівський стверджує, що «Крутий» за два роки в УПА вивчив українську мову, хоча до цього жив у Ленінграді, а його дід був управителем маєтку Терещенка, відтак сина направив у Петербург на навчання (Федорівський, 1962: 54); 7) Костянтин Караєв-«Кацо» ${ }^{12}$ (м. Владикавказ); 8) Данило Міршук-«Клименко» ${ }^{13}$; 9) «Шалений»; 10) Дмитро Вітовський-«Зміюка» ${ }^{14}$; 11) Остап Линда-«Ярема» ${ }^{15}$ (ГДА СБУ. Ф. 13. Спр. 372. Т. 4. Арк. 90). Лікарем у школі працював Лев Стефанович-«Дон» ${ }^{16}$. Сотник

завдання - будівництво залізничних доріг (зачислений військовим техніком 2 рангу). Освіта незакінчена вища. Служив у ЧА (1 залізнодорожний червонознаменний батальйон). Потрапив у полон, втік (07.1941). Учитель школи у с. Шубків Рівненського р-ну Рівненської обл. $(08$ - 12.1942). Після закриття школи перейшов працювати бухгалтером (12.1942 06.1943). В УПА з 1943. Зарахований у підстаршинську школу «Вовки» (07.1943). Інструктор із топографії старшинської школи «Дружинники» $(10.1943$ - 01.1944). Інструктор із топографії старшинської школи «Олені» $(01$ - 10.1944). Переведений у Львівську обл. Заарештований 21.11.1944, біля м. Красне Львівської обл. Засуджений 27.03.1945 ВТ Львівського військового округу по ст.ст. 54-1 «б» і 54-11 КК УРСР до 10 років позбавлення волі у ВТТ, із пораженням у правах на 5 років із конфіскацією майна. Звільнений 15.08.1950, перебував на спецпоселенні у Магаданській обл.

${ }^{8}$ Симоненко Микола («Береза»; ?, Донбас - ?). За спеціальністю інженер. Лейтенант ЧА. Потрапив у німецький полон (1942). Член ОУН (1939). Потрапив до німецького полону, втік. Інструктор СШ «Олені» (1944). Нагороджений Бронзовим хрестом заслуги (1945). Поручник, сотник УПА (1.12.1944). Заарештований репресивними органами 12.1944 у Львівській обл.

${ }_{9}^{9}$ Максименко (Тарасенко) Андрій («Степовий»; 1918, м. Полтава - 21.04.1945, біля с. Снідавка Косівського р-ну Івано-Франківської обл.). Старший лейтенант Червоної армії (артилерія). В УПА (1944). Старшина УПА (03.1944 - ?). Займав пост інструктора підстаршинської школи УПА «Грегіт» ТВ-21 «Гуцульщина» $(04-10.1944)$. Курінний куреня «Перемога» групи «Гуцульщина» (10.1944 - ?). Очолив тактичний відтинок, командування яким через кілька днів передав поручникові «Козаку» (01.1945). Член команди відтинку ТВ-21. Нагороджений Бронзовим хрестом бойової заслуги (наказ № 9 від 1.02.1945 ВО «Говерля» 3 датою старшинства 20.02.1945). Поручник УПА.

${ }^{10}$ Бондаренко Олександр Тимофійович («Бондаренко», «Гамалія»; 1905, с. Тарасівка Пирятинського р-ну Полтавської обл. - ?). Освіта середня. Член ВКП(б) (до 1941). Капітан ЧА. Інструктор Старшинської школи «Олені» (1944). Сотник УПА. Здався у Болехівський РВ НКВС. Заарештований 10.08.1944 у Івано-Франківській обл.

${ }^{11}$ Фінтіктістов А. І. («Крутий»; ? - ?). Колишній офіцер ЧА. Інструктор СШ «Олені». Поручник УПА. Заарештований 03.1945 В Івано-Франківській обл. Колишній старший лейтенант ЧА.

${ }^{12}$ Караєв Костянтин Коспалатович («Кацо»; ?, м. Владикавказ Російської Федерації - ?). Осетин. Колишній офіцер ЧА. Інструктор офіцерської школи «Олені», яка дислокувалася у Болехівському р-ні. 14.10.1944, здався НКВС і видав СШ «Олені». Поручник УПА.

${ }^{13}$ Міршук Данило («Липовий», «Клименко», «Степан Федорівський», «Федорівський Степан»; 1912, с. Турбова Липовецького р-ну Вінницької обл. - 13.04.1988, Палм Спрінг США). Навчався у Києві, політв’язень радянських тюрем. Переїхав із Вінниці на Долинщину в с. Тростянець (03.1944). Був двічі одруженим. В УПА - 3 03.1944, курсант старшинської школи «Олені» (літо - осінь 1944), інструктор та бунчужний сотні, потім куреня «Бойки» (осінь 1944 - поч. 1945), інструктор політвиховного відділу штабу ВО «Маківка» (02.1945), співробітник підпільної радіостанції «Вільна Україна» («Афродита»; 03 - 04.1945), вишкільник осередку пропаганди Дрогобицького окружного проводу ОУН (05 - 09.1945), учасник рейду відділів УПА в Словаччину (07 - 09.1945), звідки перейшов через Австрію та Італію на Захід.1951 р. емігрував до США. Став членом Об'єднання колишніх вояків УПА, членом редколегії «Літопису УПА». Письменник. Друкувався під псевдонімами - »Степан Федорівський», «Данило Федорівський» та «Данило Вінницький». Автор публікацій і книг «Молоді паростки», «Нотатки повстанця», «У смертельному колі», «Отаман Шепель». Написав спогади «На хвилях історії». Через стан здоров’я вийшов із складу редакції «Літопису УПА» (1975). Переїхав до сина у СанДієго, Каліфорнія. ${ }^{14}$ Вітовський Ярослав-Дмитро («Андріснко», «Зміюка»; 07.07.1919, с. Брошнів Долинського р-ну ІваноФранківської обл. - 29.04.1947, м. Київ). Закінчив гімназію у м. Вільнюс (Литва) (1937). Навчався на географічному факультеті Львівського університету (1939 - 1940). Член ОУН (03.1939). Організаційний референт географічного факультету Львівського державного університету. Навчався у Першому авіаційному училищі в м. Енгельс (Росія) (1940). У званні молодшого лейтенанта проходив службу в 273-й спеціальній ескадрильї. 3 початком війни залишився у Львові, не повернувшись із відпустки до підрозділу. Працював лісничим при резиденції митрополита А. Шептицького на Рожнятівщині. В УПА - 3 1944 р. Працював інструктором у СШ «Олені» (02.1944), ад’ютантом командира школи (04.1944). Начальник військовопольової жандармерії ВО-4 «Говерля» (11.1944). Командир ТВ-24 «Маківка» (05.1945). Військовий референт Дрогобицького окружного проводу ОУН (1.06.1945 - 03.1946). Керував першим пропагандивним рейдом відділів УПА по Словаччині (17.07. - 24.10.1945). Нагороджений Бронзовим хрестом бойової заслуги. Хорунжий (25.09.1944), поручник УПА (31.08.1945). Одружений із Голобродською Галиною Констянтинівною, мав дочку Марту. Під час засідки, проведеної внутрішніми військами 215-го полку НКВС поблизу м. Сколе, 19.03.1946 його важко поранили, внаслідок чого й потрапив у полон. Засуджений 04.02.1947 до ВМП - розстрілу, страчений. Фігурант АГС «Галичани», «Лісники».

15 Линда Остап («Ярема»; 17.03.1913, с. Наконечне Яворівського р-ну Львівської обл. - 24.11.1944, біля с. Красне Рожнятівського р-ну Івано-Франківської обл.). Військовий референт Львівського обласного проводу ОУН (19143 - 1944). Командир ВО «Буг» (кін. 1943 - 04.1944). Заступник командира і командир старшинської школи УПА «Олені» (весна - осінь 1944). Поручник, майор (посмертно).

${ }^{16}$ Стефанович Лев Іванович («Роман», «Дон»; 9.09.1919, м. Кам’янець-Подільський - 23.09.1944). Проживав у м. Львів. Закінчив гімназію м. Львів. Закінчив Львівський медичний інститут (1937 - 1943). Освіта вища - медична. Асистент ка- 
Василь Брилевський-«Боровий» очолив при школі видавниче звено, де друкували навчальні матеріали (Чижевський, 1948: 42). Керівником школи з 1 березня по 15 травня 1944 р. був поручник С. Фрасуляк-«Хмель». Відтак у травні 1944 р. «Хмеля» призначили начальником штабу ВО-4 «Говерля», а командиром СШ став поручник Федір Польовий-«Поль» (Ремесло повстанця, 2007: 51). Там же перебувала сотня УПА «Гайдамаки» командира Володимир Верещинський-«Ясьміна» ${ }^{17}$, яка охороняла СШ «Олені». СШ «Олені-1», яка складалася з двох сотень курсантів, здійснювала навчання за старшинською програмою (230 осіб) у період з 1 березня до 18 липня 1944 р. Також функціонувала підстаршинська школа (сотня), де навчання проводилося за підстаршинською програмою (120 осіб), у період з 1 березня до 15 червня 1944 р. (Літопис УПА, 1992: 39). Дещо інші цифрові дані наводить Д. Вітовський-«Зміюка». Зокрема, під час слідства він розповідав, що у СШ «Олені-1» навчалися 218 осіб (очевидно, маючи на увазі старшинський склад). При цьому закінчили вишкіл 196 осіб та отримали звання хорунжого і старшого вістуна, решті не присвоїли звань через низьку успішність (Літопис УПА, 2012: 720). Після цього випускників розподілили по окремих округах, де вони продовжували здобувати практичні навики.

У липні 1944 р. розпочалося навчання СШ «Олені-2», яке тривало до жовтня 1944 р. Склад школи той самий: дві сотні вишколювалися на старшин і одна - на підстаршин (Л. Шанковський пише, що чисельність становила 300 бійців). Завдяки захопленим НКВС документам СШ «Олені» в жовтні 1944 р. довідуємося про склад другої старшинької школи. Так, «Олені-2» у серпні - вересні 1944 р. формували: одну сотню очолював командир хорунжий «Щит», чисельність (на 31 серпня 1944 р. ) - 131 особа; друга сотня - командир хорунжий Михайло Гальо-«Коник», чисельність (на 10.09.1944р.) - 119 осіб; третя сотня - командир хорунжий Федір Королюс (Королюк)-«Колчак» ${ }^{18}$, чисельність (на 17.09.1944 р.) - 124 особи. Загалом 374 курсанти (Патриляк, 2004a: 252-254). До речі, впродовж липня - серпня 1944 р. $з$ першої і другої сотні загинули, пропали, відрахували 74 курсанти (Патриляк, 2004a: 252-253). До обов'язкових дисциплін у школі належали: польова служба і партизанська тактика (читав сотник Микола Симоненко-«Береза», колишній офіцер Червоної армії (далі - ЧА), до війни науковий співробітник одного із інститутів Академії наук, у грудні 1944 р. в районі м. Золочів потрапив у полон); топографія і зв'язок (поручник Іван Мельниченко-«Степовий», війна не дозволила йому здобути повну вищу освіту в Ленінграді); «піонірська справа» (поручник А. Фінтіктістов-«Крутий», колишній старший лейтенант ЧА); зброєзнавство (поручник Костянтин Караєв-«Кацо»). Решту уроків, наприклад, із внутрішньої служби, «науки стріляння» проводили сотенні командири - хорунжі «Чмелик» і «Коник» (Літопис УПА, 1987: 189-190, 203; Когут, 1999: 12-13; ГДА СБУ. Ф. 5. Спр. 67449. Арк. 11-12; Ф. 13. Спр. 372. Т. 87. Арк. 3; АУСБУ ЛО. Спр. П-38704. Арк. 17). В СШ «Олені-2» прибув із СС «Галичина» поручник «Ткачук», який став ад’ютантом школи. Також у школі працював капеланом о. Рафаїл (Р. Хомин) (Чижевський, 1948: 62). На присягу старшинської школи «Олені-2» 21 вересня 1944 р. біля сіл Нижня і Верхня Рожанка Сколівського р-ну Львівської обл. прибули провідники Іван Гриньох-«Орлів», «Номів», Олекій Гасин-«Лицар», Дмитро Вітовський-«Андрієнко», Михайло Медвідь-«Карпович», «Сергій», Андрій Кисіль-«Голубенко» та інші (Чижевський,

федри судової медицини (1943). Член ОУН (09.1941). Заарештований гестапо (1941), за відсутністю доказів звільнений. В УПА (03.1944). Займався підготовкою медичного персоналу для відділів УПА. Лікар СШ «Олені» (05.1944). Член Снятинського повітового проводу ОУН (1944). Головний лікар УПА-«Захід». Заарештований 23.08.1944, с. Витвиця Долинського р-ну Івано-Франківської обл. Обвинувачений по ст. 54-1 «а» КК УРСР. Засуджений 13.09.1944 до ВМП - розстрілу ${ }^{17}$ Верещинський Володимир («Ясьмін»; 22.11.1916, с. Боків Підгаєцького р-ну Тернопільської обл. - 1950, Тернопільська обл.). Вояк батальйону «Роланд» (1941) та 201 батальйону «Шуцманшафт» (12.1941 - 12.1942). В УНС сотні «Трембіта» (07.1943). Командир сотні «Гайдамаки» (02.1944 - 1946). Сотня перепідпорядкована ВО «Лисоня» (10 - 11.1944$)$. Заарештований (29.10.1946). Здійснив втечу із Чортківської тюрми (07.1947), відтак переховувався самостійно на Підгаєччині. Старший булавний, хорунжий (15.04.1945), поручник (22.01.1946). Можливо, відзначений Бронзовим хрестом бойової заслуги (1945 - 1946). Ймовірно загинув у 1950-х рр. на Підгаєччині.

${ }^{18}$ Королюс (Королюк) Федір («Колчак»; 28.06.1922, с. Жовнівка Бережанського р-ну Тернопільської обл. - 1.04.1945, с. Бринь Галицького р-ну Івано-Франківської обл.). Закінчив гімназію м. Бережани, відтак навчався у Львівській політехніці. Член Юнацтва ОУН. Навчався у підстаршинській школі ОУН в Поморянах (літо 1941). Заарештований гестапо (1941), звільнений 1942. Курсант старшинської школи «Дружинники» на Поліссі (08 - 12.1943). Інструктор у старшинській школі «Лісові чорти» (12.1943 - 02.1944). Перебуває на лікуванні (02 - 05.1944). У старшинській школі «Олені» (05 - 08.1944). У штабі ВО-4 «Говерля» (09.1944 - 04.1945). Працівник штабу ТВ-22. Старший вістун. Хорунжий (6.12.1943), поручник УПА. 
1948: 67). Загалом перша і друга школа «Олені» випустила понад 600 старшин і кандидатів на старшин. Досить трагічно закінчилася доля штабу старшинської школи «Олені-2». 14 жовтня 1944 р. 14 прикордонний відділ захопив і допитав К. Караєва-«Кацо» (осетин), який на допиті зізнався про місце розташування підстаршинської школи УПА в лісі на південний схід від с. Липа (до речі, С. Федорівський у спогадах пише, що у бінокль бачили, як «Кацо» вів відділи прикордонників (Федорівський, 1962: 45-49). Охорона школи велася трьома цілодобовими польовими караулами чисельністю 10 - 12 осіб кожен, місцевість навколо табору школи була замінована із залишеними чотирма проходами. Крім того, при школі існував відділ жандармерії чисельністю близько 50 осіб, яким командував хорунжий «Шалений». На озброєнні школи було: 6 ротних мінометів, 8 ручних кулеметів, 15 автоматів, 200 гвинтівок різних систем, 650 гранат і великий запас патронів. Отримавши ці дані, чекісти 15 жовтня 1944 р. (7.00) оточили школу з чотирьох сторін, одна комендатура почала наступ на табір із південно-східної сторони дороги у західному напрямі від табору, але ця територія була щільно замінована, тому чекісти залишили для прикриття мінного поля одне відділення. Чисельність підрозділів, які залучили до ліквідації, налічували 350 бійців, командував особисто начальник 14 прикордонного відділу підполковник Туляков (ГДА СБУ. Ф. 2-Н. Оп. 87 (1951). Спр. 42. Т. 1. Арк. 27). Далі у радянських документах починаються приписки. Зазначається, що в ході бою повстанці здійснили сильний спротив, але були повністю розбиті, загинули 184 особи, 5 потрапили в полон. При цьому захопили міномет, 3 ручні кулемети, 12 гвинтівок, 5 автоматів, 5 пістолетів, радіоприймач, 2 друкарські машинки, 4 сідла, 10 коней, відзначали, що багато зброї було знищено під час бою, а також документів. Радянська сторона втратила 1 вбитого сержанта та 2 рядових, поранено 1 офіцера, 2 сержантів, 4 рядових (ГДА СБУ. Ф. 2-Н. Оп. 87 (1951). Спр. 42. Т. 1. Арк. 28; Оп. 107 (1954). Спр. 1. Арк. 198). Тобто, як і у більшості радянських документів, співвідношення між числом загиблих і вилученої зброї у рази відрізнялося. Очевидно, ситуація виглядала так, що, маючи повідомлення про можливий наступ (підозрюючи «Кацо»), навчання, завершилося і курсанти були розпущені, залишився лише штаб, який і загинув, що цілком відповідає чисельності вилученої зброї (загинуло 14 осіб).

Підстаршинська школа на Буковині була організована у грудні 1944 р. Дислокувалася у с. Конятин Путильського р-ну Чернівецької обл. Керівником школи був Назарій Данилюк-«Перебийніс» ${ }^{19}$ і заступником сотенного - Онуфрій Москалюк-«Яструб» ${ }^{20}$. Вишкіл проходили 60 осіб. Навчання було розраховане на 50 днів, однак за два тижні до закінчення довелося припинити курси через масові акції НКВС (ГДА СБУ. Ф. 65. Спр. С-13422. Т. 6. Арк. 259; Літопис УПА, 2012: 37).

У 1944 р. на Дрогобиччині діяла підстаршинська школа «Крилаті», яка складалася із п’яти чот (ГДА СБУ. Ф. 13. Спр. 376. Т. 25. Арк. 317-324). Крім згаданих вище шкіл, на терені ВО-4 і ВО-5 створили низку підстаршинських шкіл. Зокрема, на терені ВО-5 «Маківка» створили під-

\footnotetext{
19 Данилюк Назарій Степанович («Підкова», «Перебийніс», «Д-45», «Л-54»; 26.10.1910, с. Витилівка Кіцманського р-ну Чернівецької обл. - 31.10.1951, радянсько-румунський кордон). Навчався у чотирирічній сільській школі, відтак в Чернівецькій гімназії. Закінчив юридичний факультет Бухарестського університету і філологічний факультет Берлінського університету. Вільно володів німецькою, французькою, румунською, російською, польською, англійською і українською мовами. Служив у румунській армії. Перекладач при генералі німецької армії. Поступив на юридичний факультет Чернівецького університету. Адвокат у м. Чернівці. В’язень румунських тюрем (1938). Разом 3 дружиною Луцією перебралися до Німеччини (1940). Член Берлінського філіалу ОУН (1941). Викладав право у Львівській українській поліційній школі (1942 - 03.1944). Член ОУН (1934). Командир сотні (весна 1944 - літо 1945), а відтак Буковинського куреня (11.1944 - 04.1945). Член Коломийського окружного проводу ОУН (1946 - 1951). Заступник командира підвідділу під час рейду в Румунію (06 - 07.1949). Референт пропаганди Коломийського окружного проводу ОУН (? - 10.1951). Одружився з Лучією «Карличук-Люся», «Галина» (? - заг. 1944), студенткою медичного інституту (кін. 30-х рр.). Фігурант АС «Карпати».

${ }^{20}$ Москалюк Онуфрій Ількович («Яструб»; 1918, с. Чорногузи Вижницького р-ну Івано-Франківської обл. - кінець 1980-х, м. Калгарі, Канада). Член ОУН (1938). Станичний ОУН у с. Чорногузи Вижницького р-ну Івано-Франківської обл. Заарештований румунськими жандармами, але втік до Галичини (1942). В УНС з липня 1943. Кулеметник ВОП «Різуна», командир рою, згодом чоти сотні «Змії», відтак командир сотні «Змії» куреня «Скажені» ТВ-22 (07.1943 - 08.1944). Переведений на Буковину (08.1944). Викладач партизанської тактики у підстаршинській школі УПА, командир сотні Буковинського куреня УПА $(08.1944$ - 04.1945). Із залишками куреня пробився на Коломийщину та влилися до складу куреня «Перемога» Ю. Матвіїва-«Недобитого» ТВ-21 «Гуцульщина» (поч. 04.1945). Перейшов на терен Румунії (05.1945 - 1947$)$. Перебрався на Захід. Проживав у м. Калгарі, Канада. Булавний УПА.
} 
старшинську школу (сотню) «Крилаті»: 1) командир Іван Гудзоватий-«Петрович» ${ }^{21}$ (весна - літо 1944 р.); 2) викладач старший булавний Василь Кошельник-«Зір» 22 ; 3) чотовий «Діль» (можливо, це «Біль»); 4) старший булавний «Скорич» 23 с с. Отиневичі, район Ходорів; 5) підхорунжий «Кармелюк» - учитель гімназії у м. Дрогобич (ГДА СБУ. Ф. 13. Спр. 372. Т. 5. Арк. 325). Сотня підстаршин «Петровича» (1 половина 1944 р.) складалася із чотових «Орла», «Вікторії», «Скорича» (ГДА СБУ. Ф. 6. Спр. 36617фп. Т. 1. Арк. 44-45). Закінчила навчання 27 липня 1944 р. На терені ВО-4 «Говерля» (Станіславська область) у групі «Гуцульщина» створили також підстаршинську школу (весна - літо 1944 р.), після закінчення якої курсанти влилися у відділи УПА. У січні 1945 р. на Гуцульщині сформували підстаршинську школу УПА, яку очолив поручник А. Максименко (Тарасенко)-«Степовий», заступники - А. Злобін-«Лісовий». У лютому курсанти закінчили навчання (Ремесло повстанця, 2007: 94-95; ГДА СБУ. Ф. 13. Спр. 372. Т. 39. Арк. 47). 3 Калущини в ролі інструктора туди відійшов хорунжий «Чмелик» (Ремесло повстанця, 2007: 94-95; ГДА СБУ. Ф. 13. Спр. 372. Т. 39. Арк. 47; Літопис УПА, 1992: 40). Зробили спробу у липні 1943 р. зорганізувати підстаршинську школу біля с. Майдан Дрогобицького р-ну. Однак німецькі окупанти одразу виявили іï та розбили.

У травні 1944 р. організували першу старшинську школу УПА імені полк. Є. Коновальця на Гуцульщині, яку очолив Федір Стефанович-«Кропива» ${ }^{24}$. До неї увійшла середньо-шкільна молодь 3 Коломийщини, яка не змогла потрапити до СШ «Олені-1». Навчання розпочалося 1 червня і тривало до 15 вересня 1944 р. Ця школа розташовувалася на хут. Буковець с. Брустури Косівського р-ну, в ній навчалися і закінчили навчання 31 особа (за результатами випускники були рекомендовані на посади: сотенних - 1, чотових - 23, ройових - 7 (ГДА СБУ. Ф. 65. Спр. С-13422. Т. 2. Арк. 213; АУСБУ ІФО. Спр. $3100 П$. Арк. 15зв.). Навчання у школі було розраховане на шість місяців, але у зв'язку із проривом лінії фронту радянськими військами на території Косівського і Жаб'ївського р-ну навчання у школі перервали, а всі, хто там перебував, пішли у відділи УПА ТВ-21 «Гуцульщина» (ГДА СБУ. Ф. 2-Н. Оп. 108 (1954). Спр. 2. Т. 2. Арк. 6). Навчання включало: 1) орієнтування на місцевості; 2) топографію; 3) санітарну справу; 4) стройову підготовку; 5) вивчення зброї; 6) одна година кожного дня відводилася на політико-пропагандистський вишкіл (АУСБУ ЧО. Спр. 7334. Арк. 10, 44зв.) (АУСБУ ЧО. Спр. 7334. Арк. 10, 443 в.). 15 вересня 1944 р. на організованих урочистостях виступали керівники ОУН і УПА: окружний ОУН

\footnotetext{
${ }^{21}$ Гудзоватий Іван Петрович («Дністровий», «Петрович»; 1911 р. с. Кадобна Калуського р-ну Івано-Франківської обл. - ?). Закінчив 5 кл. народної школи, відтак приватно навчався Василя Барнича та у приватній гімназії м. Долини (1924 - 1925), продовжив навчання у гімназію у м. Станіславів (осінь 1925 - 1932). Призваний до польської армії (09.1932), демобілізований (весна 1933), через загострення хвороби серця. Робить спробу поступити у Львівський університет (оснь 1933). Бухгалтер сільської кооперації (08.1934). Всутпає на навчання у Краківський університет (заочна форма) (09.1934). Працює в сільській «Просвіті» (1934), керує драматичним гуртком. Член ОУН (1938). Провідник станичного проводу с. Кадобна Калуського р-ну Івано-Франківської обл., відтак Голинського підрайонного проводу ОУН (03.1939). Заарештований польською владою і ув'язнений у Станіславській тюрмі (08 - 09.1939). Переходить на територію Польщі (11.1939 - 11.1941). Інструктор повітового Союзу кооперативів у м. Калуш (01.1942 - 01.1944). Військовий референт Станиславівського обласного проводу ОУН (1942-1943). Провідник Калуського міського проводу ОУН (06 - 12.1943). Інструктор у старшинській школі «Олені 1» (06.1944). Командир підстаршинської школи «Крилаті» (05 - 07.1944) ВО-5 «Маківка». Організаційний референт Станиславівського обласного проводу ОУН (осінь 1944). Захворів туберкульозом та легалізувався за допомогою довідки на ім'я Кравчука Івана Дмитровича, 1906 р.н., переселенця з Польщі Працівник зеленого господарства м. Івано-Франківсь, відтак бухгалтер у цьому господарстві (02.1946). Одружується на дочці священика о. Івана Устияновича - Зеновії із с. Старий Лисець Тисменицького р-ну Івано-Франківської обл. (02.1944). 3 дружиною виховували двох дітей: дочку Ірину (1946 р.н.) і сина Мар'яна (1950 р.н.). Заарештований 27.12.1950 р. Засуджений 11.04.1951 р. на 25 років ВТТ і 5 років пониження у правах. При перегляді справи 19.01.1955 р. вирок залишили без змін. Хорунжий УПА.

${ }_{22}^{2}$ Кошельник Василь Григорович («Зір»; 1918, с. Золотарівка Кобеляцького р-ну Полтавської обл. - 04.08.1949, с. Лімна Турківського р-ну Львівської обл.). Служив в дивізії «Галичина». Викладач підстаршинської школи УПА «Крилаті» ВО-5 «Маківка» (1944). Вступив у сотню «Біра». Референт СБ Турківського районного проводу ОУН (04.1948 - 08.1949).

${ }^{23}$ «Скорич» (?, с. Отиневичі Жидачівського р-ну Івано-Франківської обл. - ?). Старший булавний, відтак чотовий підстаршинської школи УПА «Крилаті» ВО-5 «Маківка» (1944).

${ }^{24}$ Стефанович Федір Володимирович («Кропива», «Кара-Казбек»; 1883, м. Вашківці Чернівецької обл. - ?). Освіта вища технічна. Закінчив кавалерійську школу австро-угорської армії та військову академію у Відні, підполковник Української Галицької Армії (1919). Співробітник штабу УПА-«Захід». Співпрацював із підпіллям ОУН, начальник підстаршинської та старшинської школи УПА «Грегіт» на Коломийщині (04 - 07.1944). Підполковник УГА. Заарештований 30.04.1945. Звільнений.
} 
Г. Легкий-«Борис», начальник школи «Кропива», «Степовий» (ГДА СБУ. Ф. 5. Спр. 67616. Т. 5. Арк. 335). Викладачами у школі були: 1) Ф. Стефанович-«Кропива» викладав інженерну справу і теорію кінної їзди; 2) керівник навчальної частини школи поручник «Степовий» - топографію; 3) поручник «Лісовий» - стройову і дисциплінарну службу; 4) поручник Микола Іванов-«Омельченко» - тактику; 5) капітан Т. Гачіч-«Гот» ${ }^{25}$ - теорію балістики і зброї; 6) референт пропаганди Карпатського крайового проводу ОУН В. Тодорюк-«Тур»- історію ОУН, історію України, ідеологію українських націоналістів, історію української літератури (ГДА СБУ. Ф. 2-Н. Оп. 108 (1954). Спр. 2. Т. 2. Арк. 7). Крім згаданих вище, потрібно відзначити, що при сотнях існували школи (із терміном навчання один місяць) з підготовки молодшого командного складу (ГДА СБУ. Ф. 2-Н. Оп. 55 (1953). Спр. 6. Т. 1. Арк. 106, 156). Одразу після випуску старшинської школи керівництво ВО 4 «Говерля» почало організовувати підстаршинську школу УПА біля с. Жаб’є, однак радянські репресії перешкодили зреалізувати цей задум. Відтак 90 потенційних курсантів змушені були повернутися у відділи УПА.

Також в Карпатах були організовані курси радистів, керівник - «Кирило». Навчалася ця група радистів у червні 1944 р. на Закарпатті, організаційно-технічну допомогу надали угорці (Чижевський, 1948: 60-61).

Підстаршинську школу УПА «Беркути» організували у липні 1944 р., вона діяла впродовж серпня - вересня 1944 р. у Станиславівській окрузі ОУН, командиром був хорунжий «Чмелик». База школи розташовувалася г. Малиновице в Карпатах (Літопис УПА, 1978: 92; Ремесло повстанця, 2007: 48, 259).

На терені Калуської округи впродовж травня - серпня 1944 р. діяла школа кадрів ОУН «Тигри» (база в Долинщині), яка складалася із двох сотень курсантів (чоловіча і жіноча). Керівником школи був Михайло Федоришин-«Стефаник», потім - П. Федун-«Волянський», його помічник Всеволод Лемеха-«Осип», «Тигрис». Командиром жіночої сотні була Ірина Савицька (у заміжжі - Козак)-«Бистра», iї помічницею - Марія Юрчак-«Наталка» (Содоль П. , 1995: 81). На червень 1944 р. школа налічувала 180 осіб, з них 98 жінок. Через брак харчів жіночу школу перевели у Калущину. У серпні 1944 р. в час переходу фронту школу розпустили. Чоловічу сотню включили до СШ «Олені-2».

В. Чижевський-«Демид» пише, що завдяки інтенсивній роботі старшинських шкіл Станиславівщини Львівщина та Дрогобиччина отримали по кількадесят інструкторів, але остання не зуміла їх належно використати, позитивні зміни сталися лише коли на пост командира цього терену заступив ад’ютант старшинської школи Д. Вітовський-«Зміюка» (Чижевський, 1948: 82).

Характеристику повстанців на конференції керівництва Карпатського краю ОУН 22 жовтня 1945 р. біля с. Сукіль Болехівського р-ну подавав М. Твердохліб. Він звітував про проведені вишколи і перевишколи офіцерів та підофіцерів, заняття у двох підофіцерських школах (тривало по 165 годин кожне). При цьому зазначав, що влітку 1945 р. 60 \% учасників УПА навчалися на мінерських курсах. Однак відчувався брак людей, здатних проводити вишколи. Літературу для навчання використовували переважно російську і частково українську (ГДА СБУ. Ф. 6. Спр. 33286фп. Т. 1. Арк. 211). При цьому М. Твердохліб констатував, що 80 \% стрільців УПА не були членами ОУН, а із командного складу - до 40 \% відповідно. За віковою характеристикою учасники УПА - це молоді люди у віці від 18 до 35 років. М. Твердохліб стверджував, що в основному в УПА перебували добровольці, а примусово брали тільки в окремих випадках. Відтак примусово мобілізовані демобілізовувалися з УПА. Наголошувалося на погано поставленій політвиховній роботі. Командний склад навчався переважно в самих відділах. Серед учасників УПА військовослужбовців інших армій було порівняно мало. Підкреслювалося, що озброєння було достатньо (ГДА СБУ. Ф. 6. Спр. 33286фп. Т. 1. Арк. 211). Звітуючи про проведені вишколи і пере-

\footnotetext{
${ }^{25}$ Гачіч Трифун («Гот»; 1915, с. Чумич Югославія - ?). Серб. Закінчив Белградську військову академію. Проходив службу у югославській армії (1936 - 1941). Поручник. Потрапив у полон (1941). Утримувався у таборах для військовополонених (Франції, Німеччини (Нюрнберг), України (Стрий). Втік із табору (11.1943). Інструктор старшинської школи УПА імені Є. Коновальця (Коломийщина) (1944). Викладав балістику і зброю. Отримав завдання від організаційного референта Коломийського окружного проводу ОУН Г. Легкого перейти в Югославію і встановити зв’язок із четниками Д. Міхайловіча. Заарештований 7.09 .1944 у с. Роїця Снятинського р-ну.
} 
вишколи старшин і підстаршин, зауважував, що заняття у двох підстаршинських школах тривало по 165 годин кожне (ГДА СБУ. Ф. 6. Спр. 33286фп. Т. 1. Арк. 211).

Програми підстаршинських і старшинських шкіл відрізнялися. На відміну від вишколу у підстаршинських школах, до програми старшинських входила низка спеціальних курсів: інтендантура, розвідка, організація війська, інструктаж, військове книговодство та кореспонденція. При цьому до старшинської школи приймали осіб, які мали відповідний освітній рівень (закінчення шести класів гімназії старого типу, чотирьох класів нового, або ж вісім - школи). Вишкіл у старшинських школах складався 3 двох частин: навчання рядових стрільців (тривалістю 361 год.) i підготовка кандидатів на старшин (409 год.). Загальна тривалість курсів - 770 год. До програми вишколу рядового бійця старшинської школи (361 год.) входили: «Полева служба» (86 год.), «Зброєзнавство» (36 год.), «Впоряд» (55 год.), «Стрілецький вишкіл» (25 год.), «Піонірка і мінерка» (34 год.), «Внутрішня Служба» (32 год.), «Теренознавство» (16 год.), «Політвиховання» (72 год.), «Санітарна справа» (2 год.). Натомість програма вишколу кандидатів на старшин УПА старшинської школи (409 год.) включала курси: «Полева служба» (106 год.), «Впоряд» (18 год.), «Стрілецький вишкіл» (16 год.), «Піонірка і мінерка» (22 год.), «Внутрішня Служба» (23 год.), «Політвиховання» (24 год.), «Санітарна справа» (8 год.), «Картознавство» (64 год.), «Інструктаж (командування)» (48 год.), «Організація війська» (30 год.), «Інтендантура» (16 год.), «Розвідка» (14 год.), «Зв’язок» (14 год.), «Військове книговодство, кореспонденція» (6 год.) (Ремесло повстанця, 2007: 260-261, 265).

Програми вишколу рядового бійця (313 год.) та кандидатів на підстаршин (241 год.) УПА підстаршинської школи охоплювали такий самий набір предметів, щоправда, на них відводилася дещо менша кількість годин і викладалася дещо менша кількість предметів (у вишколі кандидатів на підстаршин були відсутні «Інструктаж (командування)», «Інтендантура», «Розвідка», «Військове книговодство, кореспонденція») (Ремесло повстанця, 2007: 270). Використовувалися також програми для підстаршинських шкіл за скороченим варіантом.

Навчання стрільців у відділах УПА грунтувалося на програмі, наведеній вище. Перед керівництвом УПА стояло завдання у короткі терміни вишколити стрільців. Так, рядовий стрілець мав засвоїти основні обов'язки, навчитися діяти у складі рою, чоти, сотні, виконувати команди, здобути навики стрільби, ознайомитися з різними видами зброї, основами мінерської справи та внутрішнім розпорядком військового підрозділу. Здобуті теоретичні навики стрільці мали відточувати та вдосконалювати у бойових акціях. Окремим пунктом роботи було політичне виховання стрільців. Методика проведення політвиховної роботи викладалася у спеціальних інструкціях, а також у праці «Політвиховник - різьбар душ повстанців» С. Фрасуляка (Ремесло повстанця, 2007: 284-286).

23 червня 1946 р. політвиховник ТВ 23 «Магура» провів перевишкіл політвиховників відділів і підвідділів. Були розглянуті такі теми: «Від соц. гасел до побудови імперії» та «Сталінсько-більшовицький імперіялізм в світлі закордонної політики» (2 год.), «Міжнародне положення» (3 радянської преси) (1 год.), «Рішучість українського повстанця» (1 год.) (Літопис УПА, 1990: 128).

Для ефективного навчання необхідно було мати і відповідну фахову літературу. Знову ж таки цю проблему слід було розв'язувати за рахунок захоплених чи здобутих вишкільних видань у регулярних армій супротивника, що допомогало не лише навчатися військової справи, але й ознайомлюватися $з$ тактикою супротивника, готувати контрзаходи. Саме тому у вказівках (в.о. начальника вишкільного відділу хорунжого «Щита») окружним провідникам і командирам відтинків із ВО «Говерля» (8 липня 1945 р.) наголошувалося, що після кількаразового переходу через територію фронту серед іншого залишилася значна кількість військово-вишкільної літератури та цінних матеріалів. Однак, як відзначалося, чомусь ніде не проявили ініціативи зібрати цей цінний матеріал, якого так не вистачало. Для виправлення становища рекомендувалося: 1) до 30 вересня 1945 р. зібрати з цілого терену та з усіх відділів УПА всю військову літературу і карти (різними мовами: українською, польською, німецькою, іншими), у відділах залишити тільки підручники, потрібні для вишколу, та військові карти теренів, на яких відділ мав місце своєї постійної дислокації; 2) із зібраної літератури потрібно було до 15 жовтня 1945 р. укомплектувати бібліотеку і призначити для іiї ведення окрему відповідальну особу; 3) окремо до 15 жовтня 1945 р. потрібно було упорядкувати всі зібрані військові карти і створити при КВШ пункти військових карт (ГДА 
СБУ. - Ф. 13. - Спр. 376. - Т. 62. - Арк. 148). Тобто, у складних умовах використовувалися будьякі можливості для якісної підготовки власних військових кадрів.

Висновки. Підсумовуючи питання вишколів командного і рядового складу, відзначаємо: ведучи боротьбу за відновлення власної держави, першочерговим завданням для українських повстанців було забезпечення власних структур професійними кадрами. Розв'язувалося це питання шляхом організації власних вишкільних курсів, підготовкою та проведенням яких займалися досвідчені повстанці, які пройшли військову службу в арміях інших держав та здобули безпосередній бойовий досвід. Яскравим підтвердженням ефективної роботи вишкільних структур ВО «Говерля» стало майже десятирічне протистояння українського визвольного руху радянській репресивно-каральній системі

У публікації подається протокол допиту організатора та керівника першої старшинської школи УПА імені полк. Є. Коновальця на Гуцульщині Федора Стефановича-«Кропиви». Відзначимо, що публікований документ є важливим джерелом до комплексного дослідження українського визвольного руху загалом, особливостей підготовки старшинських і підстаршинських кадрів, зокрема. У власних зізнаннях Ф. Стефанович описує місце дислокації, чисельність, називає керівний склад старшинської школи. Крім цього подає загальну інформацію про керівний склад ОУН і УПА на Станиславівщині.

У виданні максимально збережено лексику, авторські та редакторські особливості джерел. Без змін подано власні та географічні назви. Виправленню підлягали лише найбільш очевидні граматичні огріхи. Кожен документ супроводжується легендою, в якій зазначено місце зберігання документа (назва архіву, номер фонду, опису, справи, аркушів).

\section{ПРОТОКОЛ ДОПРОСА}

Документ

Арестованного СТЕФАНОВИЧА Федора Владимировича, 1883 года рождения, урож. села Вашковцы, Черновицкой области, украинец, имеет высшее техническое образование. В последнее время находился в бандах УПА группы «Гуцульщина», имел звание полковника.

ВОПРОС: Расскажите кратко свою автобиографию?

От 21-го июня 1945 года

ОТВЕТ: До службы в австро-венгерской армии, я учился. Имею высшее лесотехническое образование. После призыва на военную службу окончил офицерскую школу и все время работал на интендантских должностях, последняя моя должность в австро-венгерской армии - старший помощник начальника интендантской службы штаба дивизии, имея звание майора.

В 1919 г. был призван на службу в УГА (Украинская Галицкая армия). Служил до 1921 г. включительно, занимал должность начальника мастерских дивизий по вещевому обеспечению. В том же году был повышен в звании до подполковника. Участия в боевых походах против Красной Армии не принимал.

По окончанию военных событий в период гражданской войны возвратился к семье на Галичину и работал на Станиславщине по лесоустройству и эксплуатации. В начале марта 1944 г. я попал в банду УПА и 6 месяцев находился на Гуцульщине.

ВОПРОС: Каким образом Вы попали в УПА и какую роль выполняли?

ОТВЕТ: В УПА я был взят принудительно по распоряжению заместителя Коломийского окружного проводу ОУН «БОРИСА» ${ }^{26}$, использовался, как военный специалист. Согласно назначения являлся начальником 1-й старшинской гуцульской окружной школы.

\footnotetext{
26 Легкий Григорій Йосипович («Борис», «30», «200», «300»; 21.06.1922, с. Слов’ятин Бережанського р-ну Тернопільської обл. - 20.10.1950р., біля с. Шешори Косівського р-ну Івано-Франківської обл.). Член ОУН (1930-ті). Освіта середня. Пропагандист Станиславівського повітового проводу ОУН (1941). Організаційний референт Городенківського повітового проводу, військовий референт Городенківського повітового проводу (1942), відтак Коломийського повіту (1943 - 1945). Організаційний референт Коломийського окружного проводу ОУН (1944 - 03.1945). Провідник Коломийського окружного проводу ОУН (03.1945 - 10.1950). Член Карпатського крайового проводу ОУН (1947 - 10.1950). Загинув разом із В. »Савчаком-Сталем». Нагороджений Срібним хрестом заслуги (ч. 2/48 від 2.09.1948 р.). Фігурант АС «Гірські», «Карпати». Одружений із Оленою «Михнюк-Зелена».
} 


\section{$[\ldots]$}

ВОПРОС: Продолжайте показания, где находилась Старшинская школа УПА, как долго Вы в ней работали, сколько сделано выпусков и охарактеризуйте преподавательский состав школы?

ОТВЕТ: Первая гуцульская школа старшин УПА находилась сначала в с. Брустури, а затем в с. Снидавка, Косовского района, Станиславской области. В школе я работал три с половиной месяца. За это время был сделан лишь один выпуск. Общий состав школы - 40 человек, 6 преподавателей, 31 курсант, машинистка, повар и помощник повара.

Комплектованием школы курсантским составом руководил Коломийский окружной провод ОУН. Слушательский состав подбирался физически здоровый и каждый из курсантов имел образование не ниже среднего.

По окончанию школы из общего количества 31 курсанта были выпущены с оценкой способностей для назначения в УПА на должности: сотенный - 1, четовых - 23, роевых - 7 .

Мне известно, что выпущенный из школы сотенный по псевдониму «КРУК» ${ }^{27}$, фамилию и имя не знаю, родом, якобы, из села Березов, Яблоновского района. Сейчас «КРУК» работает помощником начальника штаба группы УПА «Гуцульщина» «КОЗАКА».

В группе преподавателей состояли:

1. «СТЕПОВОЙ», фамилии не знаю, родом из Полтавщины, бывший командир Красной Армии, ст. лейтенант артиллерии, во время оккупации немцами восточной Украины, где-то работал учителем в школе, при отступлении немецких войск, бежал вместе сними и добровольно поступил в УПА. В школе старшин преподавал топографию и заведовал кадрами школы.

2. «ЛЕСОВОЙ» «БУГУН», фамилии не знаю, прибыл вместе с «СТЕПОВЫМ» из Полтавщины, бывший командир Красной Армии, лейтенант артиллерии. По его рассказам в 1941 г. из Красной Армии дезертировал. Где и кем он на Полтавщине работал не знаю. В школе старшин преподавал уставы внутринней и полевой службы УПА и одновременно являлся комендантом учебной роты.

3. «ОМЕЛЬЧЕНКО» ИВАНОВ, имя и отчество не знаю, бывший командир Красной Армии, родом из Киева, до войны работал в Станиславе в Облземотделе. При немцах жил в Киеве и с ними бежал на Запад во время отступления. Семья его - жена и двое детей проживают поселок Завоело, Яблоновского района. В школе старшин преподавал тактику.

4. «ЯВОР» бывший поручник румынской армии, данных о его настоящей фамилии не знаю. В школе старшин преподавал стрелковое дело. Работал примерно месяц, после чего был направлен на Буковину руководителем жандармерии, его сменил по преподаванию цыкла стрелкового дела серб «ГОТ».

5. «ГОТ» по фамилии ГАЧИЧ, каким образом он попал в УПА не знаю. По неточным данным, он, якобы, также поймал во время облавы и арестован органами НКВД.

6. «НЕЗАБУДЬКО» ТКАЧУК, родом из с. Шешоры, Косовского района, имеет высшее медицинское образование. В школе преподавал гигиену и скорую помощь.

Периодически еще читал в школе лекции воспитательного характера в духе идеологии ОУН проводник ОУН Буковины «ТУР» ${ }^{28}$. Фамилии его не знаю, по профессии адвокат, уроженец

\footnotetext{
27 Геник Костянтин Степанович («Крук», «149»; 1920, с. Нижній Березів Косівського р-ну Івано-Франківської обл. - 01.12.1950, урочище Петричила між сс. Шешори і Прокурава Косівського р-ну Івано-Франківської обл.). Закінчив 7 кл. школи у с. Нижній Березів. Закінчив вечірню школу $(1939$ - 1941). Навчався у м. Івано-Франківськ. Член ОУН. Заарештований гестапо (1941), втік. Провідник юнацтва районного проводу. Референт СБ Косівського повітового проводу ОУН (1941 - 1944). Організував і очолив сотню групи УПА «Гуцульщина» (1944). Референт СБ Косівського надрайонного проводу ОУН (1945). Заступник референта СБ Коломийської окружного проводу ОУН (літо 1946 - 12.1950). Поручник УПА. Фігурант АС «Карпати».

${ }^{28}$ Тодорюк Володимир Істратійович («Тур»; 1910, с. Стара Жадова Сторожинецького р-ну Чернівецької обл. - 05.1945). Адвокат. Член ОУН (1930). В’язень румунських тюрем (1937). Учасник Південної похідної групи ОУН, секретар міської управи м. Миколаєва (1941). Заарештований румунською сигуранцою у м. Радівці і перебував короткостроково у Бухарестській в’язниці (1942). Після звільнення, через переслідування сигуранци перебрався до Галичини. Референт пропаганди Коломийського окружного проводу ОУН (1944). В.о. провідника Буковинського обласного проводу ОУН після арешту Артемізії «Галицької-Мотрі» та загибелі Мирослава «Кіндзірського-Степана», водночас обласний організаційний референт (01 - 02.1945). Референт пропаганди Карпатського крайового проводу ОУН (03 - 05.1945). Розстріляний за підозрою у зраді. Фігурант АС «Гірські».
} 
гор. Черновцы, бывший поручник, румынской армии, имеет примерно 31 лет, низкого роста, брюнет, лицо круглое, плотного телосложения.

ВОПРОС: Какую работу в УПА Вы проводили в остальное время после окончания учебы в старшинской школе. Имели ли Вы в УПА специальное звание. Назовите свой псевдоним?

ОTВЕТ: После окончания учебы в школе старшин я со всей группой преподавательского состава был направлен в распоряжение проводника Коломийского окружного провода ОУН «СТАЛЯ». «СТАЛЬ» дал нам задание отправиться в поселок Замагура, Жабьевского района и организовать подстаршинскую школу по переподготовке младшего командного состава действующих сотен УПА. Начальником школы был назначен «СТЕПОВОЙ», а я ввиду старости лет был оставлен лектором по цыклу преподавания инженерного и конного дела, и административная служба в УПА.

В сентябре 1944 г. мы школу подстаршин организовали, но ввиду приближения фронта ее расформировали. Согласно указаний штаба УПА округа на базе школы сформировали учебный курень в составе 4-х сотен во главе которого стал «СТЕПОВОЙ». Меня в этот курень назначили помощником интеданта «НЕЧАЯ».

Задачей куреня являлось обучение создаваемых новых сотен группы УПА Гуцульщины.

В ноябре месяце 1944 г. я заболел на тиф и по болезни из куреня «СТЕПОВОГО» выбыл. Болел до апреля 1945 г. По выздоровлению снова был вызван «БОРИСОМ» для назначения на работу. Предлагали мне стать пропагандистом окружного провода ОУН, но вопрос окончательно не был разрешен, так как сразу же после того проходила облава и я добровольно сдался войскам в плен.

Во время присвоения званий командному составу УПА по приказу штаба УПА Края «Запад», как об этом сообщил мне заместитель проводника Коломийского окружного провода ОУН «БОРИС», в апреле месяце 1945 г. мне было утверждено звание полковника УПА и в обращении меня называли уже полковником. Псевдоним я имел «КАРАКАЗБЕК», сначала имел псевдоним «КРОПИВА».

ВОПРОС: Расскажите какие Вы знаете вооруженные банды УПА, действующие на Гуцульщине, их численный состав и вооружение?

ОTВЕТ: По данным, которым я располагал в апреле месяце 1945 г. на гуцульщине действовали ряд куреней УПА, обеднённые в группу «Гуцульщина», которой командует «КОЗАК» ${ }^{29}$. Характеризуя каждый курень в отдельности, я знаю следующие:

1. Курень «СКУБЫ» ${ }^{30}$. Состоит из 4-х сотен, в составе куреня насчитывается до 700 чел., на вооружении имеется 6 орудий горно-легкой артиллерии разных калибров, $6-8$ ротных минометов, до 25 станковых и до 100 шт. легких пулеметов, в достаточном количестве имеет автоматов и винтовок. 16 апреля с.г. курень пополнился в людском составе на 70 чел.

Куренным этого куреня является «СКУБА», фамилии его не знаю, откуда родом также неизвестно, лично его видел несколько раз, лет ему 30 - 35, высокий, плотного телосложения, имеет военное образование, которое получил в немецкой армии. В военном отношении грамотный. Часто бывает в рейдах по Закарпатской Украине.

\footnotetext{
29 Яворський Микола («Козак», «Здоровенко»; 1916, Тернопольській обл. - 29.01.1946, біля с. Поляниця тепер у складі Яремчанської міськради Івано-Франківської обл.). Член ОУН. Служив у Польському війську. Воював у легіоні «Нахтігань» $(04.1941$ - 12.1942). В УНС (07.1943). Очолив 3-ю сотню у курені УНС «Чорні чорти» імені Євгена Коновальця $(08$ - 11.1943). Курінний. Створив першу бойову сотню на Гуцульщині, яка воювала проти німців і угорців (11.1943). Призначений командиром усіх частин УПА в Коломийській окрузі (25.03.1944). Командир першого куреня на Гуцульщині, опісля командир Коломийського загону. Військовий референт Коломийського окружного проводу ОУН (01.1945 - 01.1946). Командир ТВ-21 «Гуцульщина» (01.1945 - 1946). Нагороджений Срібним хрестом бойової заслуги 2-го класу (наказ 1/45, від 25.04.1945). Старший булавний, поручник (15.04.1945), сотник (літо 1946), майор (29.01.1946). ${ }^{30}$ Гах Дмитро Миколайович («Скуба»; 1919, с. Хриплин Івано-Франківської міської ради - 27.09.1945, біля м. Коломия Івано-Франківської обл.). Член ОУН. Член «Просвіти». Член братства «Тверезість». Працював робітником на залізниці. 1940 р. мобілізований до Червоної армії, командир танка. Вступив до легіону «Нахтігаль», лейтенант (1941 - 01.1943$)$. Чотовий у курені УНС імені Євгена Коновальця «Чорні чорти» (07.1943 - весна 1944). Командир сотні «Сурма» (весна - 10.1944). Курінний куреня «Гайдамаки» ТВ-21 «Гуцульщина» (10.1944 - 09.1945). Старший булавний (10.1944), хорунжий (04.1945), сотник, майор (посмертно). Нагороджений Срібним Хрестом Бойової Заслуги 1-го класу (наказ 1/45 від 25.04.1945). Похоронений між сс. Кривоброди і Пилипи Коломийського р-ну Івано-Франківської обл.
} 
2. Курень «КНЫША» ${ }^{31}$. Состоит из 4-х сотен, в составе куреня насчитывается до 600 чел., на вооружении имеет 4-легких орудия, 4 ротных миномета, много легких пулеметов.

Одна сотня этого куреня вооружена исключительно станковыми пулеметами которых насчитывается до 20 шт.

Куренным этого куреня является «Кныш», фамилии и откуда родом не знаю. Лично его видел два раза. Ему лет 30 низкого роста, блондин, полный, волос зачесывает назад, одет в форму венгерского солдата, как командир слабый.

3. Курень «НЕДОБИТОГО ${ }^{32}$, состоит из 3-х сотен с общим количеством людского состава до 200 чел. В этом курене продолжительное время свирепствовала эпидемия тифа, кроме того Косовском районе он был рассеян войсками Красной Армии, поэтому по оценке боеспособности его считают слабым. На вооружении имеет легких орудия, 1 ротный миномет, 6 станковых и до 20 легких пулеметов.

Куренным этого куреня является «НЕДОБИТЫЙ» фамилии и откуда родом не знаю. Лично его видел два раза. Ему лет 30, низкого роста, полный, блондин, фамилии и откуда родом не знаю. При немцах в Кутах работал комендантом полиции, имеет высшее юридическое образование.

4. Курень «ИСКРЫ» состоит из 3-х сотен, с общим количеством людского состава до 300 чел., на вооружении имеет 2 ротных миномета, 4 станковых и 8 легких пулеметов, остальное вооружение - винтовки и автоматы.

Куренным этого куреня является «ИСКРА», лично его не видел и о нем ничего сообщить не могу. Куренным «ИСКРА» был назначен в начале января с.г., до него этым куренем командовал «ЛЕСНОЙ» ${ }^{33}$, который умер от тифа.

5. Курень «ПЕРЕБЕЙНОС $»^{34}$. Состоит из 3-х сотен, с общим количеством людского состава до 200. В прошлом году этот курень имел до 800 чел., много людей потерял в результате эпидемии тифа, облав и дезертирства. На вооружении имеет 2 легких орудия, 2 миномета, 6 станковых и 16 ручных пулеметов, автоматы, винтовки.

Куренным этого куреня является «ПЕРЕБЕЙНОС», лично его видел несколько раз, лет 35 , высокий, худощавый, брюнет, фамилии настоящей не знаю. Родом из Буковины, имеет высшее

\footnotetext{
${ }^{31}$ Горнякевич Дмитро («Книш», «Мурза», «Ратай»; 1909, смт. Букачівці (с. Чернів) Рогатинського р-ну Івано-Франківської обл. - 31.10.(02.11.)1946, с. Космач р-н гори Лисина-Космацька Косівського р-ну Івано-Франківської обл.). Член «Просвіти», член ОУН. Вчителював на Снятинщині. Служив у польському війську. Воював в українському легіоні «Роланд» $(04$ - 12.1941). Організаційно-мобілізаційний референт Коломийського окружного проводу ОУН (1943 - 1944). Створив і очолив сотню УПА, яка оперувала в Коломийському, Косівському, Верховинському р-нах Станіславської обл. (весна - 06.1944). Командир куреня «Гуцульський» $(10.1944-10.1946)$. Член військового штабу 21-го (Коломийського) тактичного відтинку УПА «Гуцульщина» (01.1946). Військовий референт Коломийського окружного проводу ОУН (1943 - 1944). Булавний, хорунжий (15.04.1945), поручник (22.01.1946). Фігурант АГ «Горні».

32 Матвіїв Юліан Миколайович («Кріс», «Любомир», «Недобитий», «Л-13», «М-14», «2М», «01», «12-48»,»227a», «0-13», «0-1»; 1914, с. Білявці Бродівського р-ну Львівської обл. - 08.04.1953, м. Київ). Походив з родини учителів. Член «Пласту». Закінчив Бродівську гімназію. Навчався на юридичному факультеті Люблінського університету (1932 - 1937) та факультеті соціально-економічних наук університету у Бельгії (1939). Магістр права, адвокат. Член ОУН (1932). Член Грубешівського повітового проводу ОУН (1940 - 1941). За завданням проводу ОУН працював секретарем української допоміжної поліції у м. Коломия Івано-Франківської обл. $(10-11.1941)$, згодом став комендантом УдП у м. Кути (11.1941 - 03.1944). Чотовий, командир сотні імені І. Богуна куреня «Гайдамаки» 03 - 12.1944), курінний УПА куреня «Перемога» (01 - 11.1945) ТВ-21 «Гуцульщина». Референт СБ Косівського надрайонного проводу ОУН (12.1945 - 09.1947). В.о. провідник Косівського надрайонного проводу ОУН (05 - 09.1947). Референт СБ Коломийського окружного проводу ОУН (09.1947 - 05.1948). В.о. референта СБ Чернівецького окружного проводу ОУН (05 - осінь 1948). В.о. референта пропаганди Чернівецького окружного проводу ОУН (весна - осінь 1949). Організаційний референт Буковинського окружного проводу ОУН (05.1948 - 07.1950). Провідник Буковинського окружного проводу ОУН (07.1950 - 05.1952). Одружився 3 Любою Якубів з м. Розділ Львівської обл. Заарештований 28.05.1952 р. під час проведення операції УМДБ Івано-Франківської обл. у с. Люча Косівського р-ну Івано-Франківської обл. разом з М. Кричуном-«Черемшиною». Згідно з вироком суду від 20.01.1953 р. засуджений за ст. 54-8 та 54-2 КК УРСР до ВМП. Розстріляний у Лук'янівській тюрмі. Нагороджений Бронзовим хрестом бойової заслуги (15.04.1945). Поручник УПА (22.01.1946). Йому присвячена книга В. Гуменюка «Повість про Недобитого» (Львів, 2005 р.). Фігурант АС «Змовники», «Кочівники», «Ядро».

33 Злобін Андрій («Богун», «Лісовий»; 1918, Полтавська обл. - 18.02.1945, с. Баня-Березів Косівського р-ну Івано-Франківської обл.). Лейтенант ЧА (артилерія). Потрапив до УПА (03.1944). Призначений інструктором підстаршинської школи УПА «Грегіт» ТВ-21 «Гуцульщина» $(04-08.1944)$. Командував куренем УПА «Карпатський» $(10.1944-04.1945)$. Нагороджений Бронзовим хрестом бойової заслуги (наказ №9 ВО «Говерля» від 1.02.1945 з датою старшинства 20.02.1945). Поручник УПА. Помер від тифу.

${ }^{34}$ Назарій Данилюк-«Перебийніс».
} 
образование, юрист. Жену его, работавшую в курене врачем, за то, что она много расходовала из аптеки УПА медикаментов на оказание медпомощи больным жителям сел, «СБ» расстреляла ${ }^{35}$.

6. Курень «КРЫГЫ» ${ }^{36}$. Состоит из 3-х сотен с количеством людского состава до 300 чел. Действовал курень на Буковине, сам куренной «КРЫГА» в бою с частями Красной Армии возле г. Кицманы Черновицкой области в январе месяце с.г. убит. Кто сейчас командует этим куренем не знаю.

На вооружении раньше курень имел 2 легких орудия, 2 ротных миномета, 6 станковых и 12 ручных пулеметов, автоматы, винтовки.

7. Группа «МОРОЗА $»^{37}$ является отдельной единицей имеет в своем составе 150 человек, вооружена только легким автоматическим оружием, достаточно маневренная. Командует группой «МОРОЗ», лет 28, среднего роста, блондин, плотного телосложения. Фамилии не знаю, родом из с. Березово Яблоновского района Станиславской области, в бывшей польской армии служил подофицером.

8. Группа «КАРАПКА» ${ }^{38}$ является отдельной единицей, имеет в своем составе до 60 человек. Вооружена легким автоматическим оружием и винтовками. В его группе имеется большое количество снайперов вооруженных винтовками со снайперскими приборами. В группе высоко поставлена дисциплина и по своей активности она считается наиболее боевой. Действует главным образом на Буковине.

Командует группой «КАРАПКА», по ухваткам типичный бандит, служил в конных частях румынской армии, имел звание младшего сержанта, фамилии его не знаю, среднего роста, брюнет, лет 35, в движениях энергичный, на левой стороне лба имеет шрам.

Кроме перечисленных куреней и групп УПА, в феврале месяце с.г. проводник ОУН на Буковине «ТУР» создал на своей территории еще два куреня с количеством стрельцов в них по 200 чел., в каждом. Из Гуцульщины на должность куренных были направлены «ТУРУ» из резерва командного состава УПА сотенные «ЛЕВКО» и «ЧЕРНЫХ».

При каждом курене и самостоятельной группе имеет по две четы - инженерно-саперная и военно-полевой жандармерии.

Кроме того, созданы из призывного контингента мужского населения, т.н. резервно-запасные сотни с целью пополнения действующих сотен УПА и для создания по необходимости новых вооруженных единиц. Таких резервно-запасных сотен на Гуцульщине насчитывается - 12 .

ВОПРОС: Что Вам известно о новых изменениях, введенных в структурном построении ОУН и УПА?

\footnotetext{
35 Дана інформація не відповідає дійсності. Щодо загибелі дружини Назарія Данилюка-«Перебийноса» Луції Данилюк-Карличук (референт УЧХ Буковинського обласного проводу ОУН (11.1944 - 03.1945) існує декілька версій.

${ }^{36}$ Додяк Олексій Семенович («Ворон», «Крига»; 1913, с. Рівня, тепер у складі м. Вижниця Чернівецької обл. - 5.10.1945, м. Івано-Франківськ). Член ОУН (08.1941). Закінчив семирічну та агрономічну школи. Служив у румунському війську, сержант піхоти (1935 - 1936). Ройовий, заступник командира сотні в Буковинському курені (08 - 11.1941). Служив в українській поліції у Києві, згодом інструктор (12.1941 - 02.1943). Вступив до УНС (10.1943). Командир сотні, яка оперувала в Верховинському р-ні Івано-Франківської обл. та гірських районах Буковини. Військовий референт Косівського повітового проводу ОУН (11.1943 - 07.1944). Військовий референт у Коломийського окружного проводу ОУН. Командир 1-ї сотні (імені полк. Д. Вітовського) Буковинського куреня УПА (літо - 11.1944). Сотенний у цьому курені (11.1944 - 02.1945). Заарештований 16.02.1945 р. смт. Яблунів Косівського р-ну Івано-Франківської обл. Засуджений 17.07.1945 р. до ВМП Військовим трибуналом військ НКВС Чернівецької обл.

37 Негрич Дмитро Миколайович («Мороз»; 26.07.1909, с. Вижній Березів Косівського р-ну Івано-Франківської обл. - 19.09.1945, біля с. Баня-Березів Косівського р-ну Івано-Франківської обл.). Член ОУН (1943). Служив у польському війську, підофіцер. Провідник районного проводу ОУН. Створив у Вижньому Березові самооборонний кущовий відділ (1940). Організував і очолив «Березівську» сотню УПА, яка ввійшла до куреня «Карпатський» (весна 1944). Сотенний куреня «Скуби» (зг. 07.1945) ТВ-21 «Гуцулыцина» ВО-4 (1944 - 1945). Сотня оперувала у Косівському, Коломийському, Надвірнянському, Верховинському р-нах Станіславської обл. та гірських р-нах Буковини, багато рейдувала. Нагороджений Бронзовим хрестом бойової заслуги (наказ №9 ВО «Говерля» від 1.02.1945, 3 датою старшинства 20.02.1945). Хорунжий УПА.

${ }^{38}$ Карапка Дмитро Іванович («Боярин»; 1916, с. Усть-Путила Путильського р-ну Чернівецької обл. - 28.04.1945, прис. Черепанка с. Мариничі Путильського р-ну Чернівецької обл.). Служив у румунській армії, звідки втік та перейшов на нелегальне становище (1936). Член ОУН. Комендант боївки ОУН (04.1944). Чотовий 2 чоти сотні Онуфрія Москалюка-«Яструба» ТВ-20 «Сучава» $(05$ - 12.1944). Командир сотні Буковинського куреня УПА (12.1944 - 04.1945). Загинув у сутичці з «істребками» на хут. Черепанка с. Мариничі Путильського р-ну Чернівецької обл.
} 
ОТВЕТ: За время моего пребывания на службе в УПА, никаких изменений в структурном построении УПА не произошло. В отношении ОУН в конце 1944 г. буковинскую организацию украинских националистов, которая до этого времени считалась самостоятельной, присоединили к коломийской окружной организации и провод ОУН Коломийского округа возглавил руководство над организацией Буковины и с того времени стал называться Коломийско-Буковинский.

ВОПРОС: Кого Вы знаете из руководящего состава Коломийско-Буковинского окружного провода ОУН?

ОТВЕТ: Из руководящего состава Коломийско-Буковинского окружного провода ОУН я знаю следующих:

1. «СТАЛЬ ${ }^{39}$ окружной проводник Коломийско-Буковинского округа, фамилии и откуда родом не знаю, лет 25 , среднего роста, плотного телосложения, шатен, лицо полное, одет в немецком мундире, часто его видел в Жабьевском районе.

2. «БОРИС» ${ }^{40}$ заместитель «СТАЛЯ», или оргреферент Коломийско-Буковинского окружного провода ОУН, имеет 26 лет, родом из Обертынского района, фамилии не знаю, среднего роста, блондин, видел его в последнее время в с. Космач 16 апреля 1945 г.

3. «ДИК» ${ }^{41}$ руководитель «СБ» окружного провода ОУН, имеет 37 лет, высокий, блондин, плотного телосложения, откуда родом и как его фамилия не знаю. «ДИК» на Коломийщине проводником «СБ» окружного провода стал в феврале 1945 г., до этого окружным проводником «СБ» был «КЛИМ», последний переведен для работы в область.

«ДИК» имеет свою боевку до 15 вооруженных человек и в составе боевки от каждого повита имеет по одному представителю для связи с повитовыми проводниками «СБ».

Никого больше из состава Коломийского-Буковинского окружного провода ОУН не знаю.

ВОПРОС: Сколько повитов входит в состав Коломийско-Буковинского округа и назовите кого Вы знаете из руководителей повитовых проводов?

ОТВЕТ: В состав Коломийско-Буковинского провода ОУН входит 7 повитов - четыре повита Коломийщины и три повита Буковины. На Коломийщине имеются повиты Коломийский, Снятинский, Косовский и Городенковский. На Буковине - Черновицкий, Вижницкий, Стороженецкий.

Из повитовых руководителей ОУН Буковины никого не знаю, а на Коломийщине повитовыми проводниками работают:

1. «ВИКТОР» проводник Коломийского повитового провода ОУН, его заместитель, или оргреферент - МИКИТЮК Зиновий, родом из Коломии, псевдоним последнего не знаю.

2. «КУРЯВА» проводник Снятинского повитового провода ОУН, его заместитель «ЧАЙКА» ЧАЙЧЕНКО.

3. «ГОНТА» ${ }^{42}$ проводник Косовского повитового провода ОУН.

4. «ТРИСКА» проводник Городенковского повитового провода ОУН.

Никого больше из состава руководства повитовых проводников ОУН Коломийщины не знаю.

\footnotetext{
${ }^{39}$ Савчак Василь Миколайович («Сталь», «Блакитний», «Андріан», «Арпад», «Сокіл», «Старий», «С-20», «383/с»; 23.03.1922, с. Ямниця Тисменицького р-ну Івано-Франківської обл. - 20.10.1950 р., біля с. Шешори Косівського р-ну Івано-Франківської обл.). Освіта середня. Закінчив народну школу та Станиславівську гімназію. Член Юнацтва (1936). Організаційний референт Станіславського обласного проводу ОУН (Юнацтва) (1940 - 1944). Провідник Коломийського окружного проводу ОУН (весна 1944 - 03.1945). Провідник Буковинського окружного проводу ОУН (03.1945 - 06.1950). Організаційний референт Карпатського крайового проводу ОУН (07 - 10.1950). Нагороджений Бронзовим хрестом заслуги (ч. 1/45 від 25.04.1945). Нагороджений Срібним хрестом заслуги (ч. 2 від 2.09.1948). Фігурант АС «Гірські», «Змовники», «Підпільники».

40 Легкий Григорій Йосипович.

41 Валько Дмитро Онуфрійович («Забіяка», «Дик»; 1909, с. Ямниця Тисменицького р-ну Івано-Франківської обл. - 19.02.1946, біля с. Перерив Коломийського р-ну Івано-Франківської обл.). Освіта середня. Перебував за кордоном (1939 - 1941). Служив у німецькій поліції. Керівник боївки СБ Коломийського окружного проводу ОУН (1944). Охоронець В. »Лівого-Йордана». Заступник референта СБ Коломийського окружного проводу ОУН (не пізніше 08.1945 - 02.1946). Можливо, це «Гарт». Фігурант АС «Гірські», «Карпати».

42 Федюк Василь Юрійович («Гонта», «Свшан», «Курява»; 01.07.1918, с. Кийданці Коломийського р-ну Івано-Франківської обл. - 12.2006, м. Коломия Івано-Франківської обл.). Організаційний референт Коломийського повітового проводу ОУН (осінь 1941 - 09.1942). Провідник Косівського повітового проводу ОУН (09.1942 - осінь 1944). Повітовий, відтак надрайонний Городенки (осінь 1944 - 05.1945). Провідник Городенківського надрайонного проводу ОУН (осінь 1944 - 05.1945). Заарештований 30.05.1945.
} 
ВОПРОС: Кого Вы знаете из состава руководства Краевого провода ОУН и Краевого штаба УПА. Видели ли Вы за время пребывания в УПА кого либо из руководителей Центрального провода ОУН?

ОТВЕТ: Из состава руководства краевого провода ОУН и штаба УПА я никого не знаю. Когда я был начальником старшинской школы, то к нам в с. Брустура, вместе с «БОРИСОМ» приходил один представитель краевого провода, но я о нем ничего сообщить не могу, так как его я видел один раз лишь.

Приметы: Низкого роста, блондин, лет 40 - 45, полный, одет в штатском платье.

Будучи в с. Космач второй раз по указаниям «БОРИСА», ходил на встречу члена краевого провода для сопровождения его в расположения школы. О нем также ничего существенного показать не могу.

Приметы: Среднего роста, брюнет, худощавый, щуплый, одет в штатской одежде.

Из состава руководства центрального провода ОУН за время своего пребывания в УПА никого не видел.

К этому хочу дополнить. В ноябре 1944 г. разговаривая один раз с «БОРИСОМ», последний мне сообщил, что немцы освободили из под ареста БАНДЕРУ Степана и МЕЛЬНИКА Андрея. Тогда же он мне говорил, что бандеровцы объединились с мельниковцами и, что, якобы, МЕЛЬНИК назначен заместителем БАНДЕРЫ. МЕЛЬНИК и генерал КАПУСТЯНСКИЙ находится, якобы, в районе г. Холм Любинского воеводства (Польща). В подтверждение правдоподобности своих сведений «БОРИС» сослался на сообщение, которое они, якобы, получили по этому вопросу с центра. Насколько это правдоподобно утверждать не могу.

ВОПРОС: Много ли имеется восточников в составе банд УПА группы «Гуцульщина»?

OTBET: В бандах УПА много восточников было тогда, когда еще стоял в Карпатах фронт. Особенно много было власовцев. Венгры совместно с УПА порядочное количество восточников с диверсионно-разведывательными заданиями перебросили через линию фронта на Советскую сторону. Перебрасывали одиночками и группами

Много также групп мадьяры вглубь СССР забросили самолетами. Несколько таких групп было выброшено на Киевщину и Полтавщину. Конкретно кого либо из них я не могу назвать, потому, что в этот период в УПА я был новый человек и никого из них не знаю. Сейчас восточников в составе банд УПА имеется очень мало.

Протокол с моих слов записан правильно, мною прочитан в чем и расписываюсь.

\section{ОПРОСИЛ: НАЧАЛЬНИК ОТДЕЛЕНИЯ № ОТДЕЛА УНКГБ КАПИТАН ГОСБЕЗОПАСНОСТИ (ФОРМАНЧУК)}

ГДА СБУ. - Ф. 65. - Спр. С-13422. - Т. 2. - Арк. 211-219.

\section{СПИСОК ВИКОРИСТАНИХ ДЖЕРЕЛ І ЛІТЕРАТУРИ}

АУСБУ ІФО - Архів управління Служби безпеки України у Івано-Франківській області.

АУСБУ ЧО - Архів управління Служби безпеки України у Чернівецькій області.

ГДА СБУ - Галузевий державний архів Служби безпеки України.

Ільницький, 2016 - Ільницький В. До питання функціонування відділів УПА на Чернівеччині (1944 1945) // Східноєвропейський історичний вісник / [головний редактор В. Ільницький]. Дрогобич, Посвіт, 2016. Вип. 1. С. 60-68.

Кентій, 1999 - Кентій А. Нарис боротьби ОУН-УПА в Україні (1946 - 1956 рр.). Київ, Інститут історії України НАН України, 1999. 111 с.

Киричук, 2003 - Киричук Ю. Український національний рух 40-50-х років XX століття: ідеологія та практика. Львів: Добра справа, 2003. 464 с.

Когут, 1999 - Когут М. Повстанська доля Байрака. Дрогобич, Відродження, 1999. 48 с.

Літопис УПА, 1978 - Літопис Української Повстанської Армії / відп. ред. С. Штендера, співред. П. Потічний. Торонто, Літопис УПА, 1978. Т. 3: Чорний ліс: видання команди Станиславівського тактичного відтинка УПА 1947 - 1948 роки. Передрук підпільного журналу УПА (1947 - 1948). Кн. 1. 272 с. 
Літопис УПА, 1987 - Літопис Української Повстанської Армії / відп.ред. Є. Штендера, співред. П. Й. Потічний. Торонто: Літопис УПА, 1987. Т. 15: Спогади командира відділу особливого призначення «УПА-Схід». $270 \mathrm{c}$.

Літопис УПА, 1990 - Літопис Української Повстанської Армії / упоряд. Петро Содоль. Торонто, Літопис УПА, 1990. Т. 18: Група УПА «Говерля». Документи, звіти та офіційні публікації: Кн. 1. 328 с.

Літопис УПА, 1992 - Літопис Української Повстанської Армії / упоряд. Петро Содоль. Торонто, Львів, Літопис УПА, 1992. Т. 19: Група УПА «Говерля». Спомини, статті та видання історично-мемуарного характеру: Кн. 2. 360 c.

Літопис УПА, 2007 - Літопис Української Повстанської Армії. Нова серія / упоряд. Олександр Іщук, Сергій Кокін. Київ, Торонто, 2007. Т. 9: Боротьба проти повстанського руху і націоналістичного підпілля: протоколи допитів заарештованих радянськими органами державної безпеки керівників ОУН і УПА (1944-1945). $912 \mathrm{c}$.

Літопис УПА, 2012 - Літопис Української Повстанської Армії. Нова серія / упоряд. Дмитро Проданик. Київ, Торонто, Літопис УПА, 2012. Т. 19: Підпілля ОУН на Буковині: Документи і матеріали. $1943-1951.840$ c.

Патриляк, 2004а - Патриляк І. «Щоденний хліб» курсантів УПА: житлове, матеріально-технічне, продовольчета медичне забезпечення старшинських та підстаршинських шкіл УПА (1943 - 1944) // Український визвольний рух / Центр досліджень визвольного руху, Інститут українознавства ім. І. Крип'якевича НАН України. Львів: Коло, 2004. Збірник 3: До 75-ліття Організації Українських Націоналістів. С. 246-259.

Патриляк, 2004b - Патриляк І. Старшинські й підстаршинські школи УПА в 1943 - 1944 pр. // Визвольний шлях. 2004. Кн. 4 (673). С. 92-106.

Ремесло повстанця, 2007 - Ремесло повстанця. Збірник праць підполковника УПА Степана Фрасуляка-«Хмеля» / ред. і упоряд. Р. Забілий. Львів, Центр досліджень визвольного руху, 2007. 424 с.

Русначенко, 2002 - Русначенко А. Народ збурений: Національно-визвольний рух в Україні й національні рухи опору в Білорусії, Литві, Латвії, Естонії у 1940 - 50-х роках. Київ: Університетське видавництво «Пульсари», 2002. - $519 \mathrm{c}$.

Содоль, 1995 - Содоль П. Українська Повстанча армія 1943 - 1949. Довідник другий. Нью-Йорк, 1995. $295 \mathrm{c}$.

Федорівський, 1962 - Федорівський С. Нотатки повстанця. Нью-Йорк: Прометей, 1962. 207 с.

Чижевський, 1948 - Чижевський В. Організація військової праці ОУН. [б. м.; б. в.], 1948. - 132 с.

\section{REFERENCES}

AUSBU IFO - Arkhiv upravlinnia Sluzhby bezpeky Ukrainy u Ivano-Frankivskii oblasti [Archive of Security Service Management of Ukraine in Ivano-Frankivsk region]. [in Ukrainian].

AUSBU ChO - Arkhiv upravlinnia Sluzhby bezpeky Ukrainy u Chernivetskii oblasti [Archive of Security Service Management of Ukraine in Chernivtsi region]. [in Ukrainian].

HDA SBU - Haluzevyi derzhavnyi arkhiv Sluzhby bezpeky Ukrainy [Sectoral State Archive of Security Service of Ukraine]. [in Ukrainian].

Ilnytskyi, 2016 - Ilnytskyi V. Do pytannia funktsionuvannia viddiliv UPA na Chernivechchyni (1944 - 1945) [Functioning of the UPA(Ukrainian Insurgent Army) squads in Chernivtsi region(1944-1945)]// Skhidnoievropeiskyi istorychnyi visnyk / [holovnyi redaktor V. Ilnytskyi]. Drohobych, Posvit, 2016. Vyp. 1. S. 60-68.

Kentii, 1999 - Kentii A. Narys borotby OUN-UPA v Ukraini (1946 - 1956 rr.) [On functioning of UPA departments in Chernivtsi land; An outline of the struggle of OUN-UPA in Ukraine (1946 - 1956)]. Kyiv, Instytut istorii Ukrainy NAN Ukrainy, 1999. 111 s. [in Ukrainian].

Kyrychuk, 2003 - Kyrychuk Yu. Ukrainskyi natsionalnyi rukh 40-50-kh rokiv XX stolittia: ideolohiia ta praktyka [Ukrainian Nationalist Movement of 1940s-1950s: Ideology and Practice]. Lviv: Dobra sprava, 2003. 464 s. [in Ukrainian].

Kohut, 1999 - Kohut M. Povstanska dolia Bairaka [The insurgent destiny of Bairak]. Drohobych: Vidrodzhennia, 1999. 48 s. [in Ukrainian].

Litopys UPA, 1978 - Litopys Ukrainskoi Povstanskoi Armii / vidp. red. Ye. Shtendera, spivred. P. Potichnyi. Toronto, Litopys UPA, 1978. T. 3: Chornyi lis: vydannia komandy Stanyslavivskoho taktychnoho vidtynka UPA 1947 - 1948 roky. Peredruk pidpilnoho zhurnalu UPA (1947 - 1948) [The Black Wood: the publication of the command of Stanislaviv tactical UPA unit]. Kn. 1. 272 s. [in Ukrainian].

Litopys UPA, 1987 - Litopys Ukrainskoi Povstanskoi Armii / vidp.red. Ye. Shtendera, spivred. P. Y. Potichnyi. Toronto, Litopys UPA, 1987. T. 15: Spohady komandyra viddilu osoblyvoho pryznachennia «UPA - Skhid» [The reminiscences of the commander of the «UPA - Skhid (UPA - EAST») special purpose department]. $270 \mathrm{~s}$. [in Ukrainian]. 
Litopys UPA, 1990 - Litopys Ukrainskoi Povstanskoi Armii / uporiad. Petro Sodol. Toronto: Litopys UPA, 1990. T. 18: Hrupa UPA «Hoverlia». Dokumenty, zvity ta ofitsiini publikatsii [The UPA group «Hoverlia»: documents, reports and official publications]: Kn. 1. 328 s. [in Ukrainian].

Litopys UPA, 1992 - Litopys Ukrainskoi Povstanskoi Armii / uporiad. Petro Sodol. Toronto, Lviv, Litopys UPA, 1992. T. 19: Hrupa UPA «Hoverlia». Spomyny, statti ta vydannia istorychno-memuarnoho kharakteru [The UPA group «Hoverlia»: reminiscences, articles and publications of historical-memoirs character]: Kn. 2. $360 \mathrm{~s}$. [in Ukrainian].

Litopys UPA, 2012 - Litopys Ukrainskoi Povstanskoi Armii. Nova seriia / uporiad. Dmytro Prodanyk. Kyiv, Toronto, Litopys UPA, 2012. T. 19: Pidpillia OUN na Bukovyni: Dokumenty i materialy [The OUN underground in Bukovyna: documents and materials]. 1943 - 1951. 840 s. [in Ukrainian].

Litopys UPA, 2007 - Litopys Ukrainskoi Povstanskoi Armii. Nova seriia / uporiad. Oleksandr Ishchuk, Serhii Kokin. Kyiv, Toronto, 2007. T. 9: Borotba proty povstanskoho rukhu i natsionalistychnoho pidpillia: protokoly dopytiv zaareshtovanykh radianskymy orhanamy derzhavnoi bezpeky kerivnykiv OUN i UPA [The struggle of the anti-insurgent movement and nationalist underground: reports of interrogations of OUN and UPA leaders arrested by the Soviet state security agencies] $(1944-1945) .912$ s. [in Ukrainian].

Patryliak, 2004a - Patryliak I. «Shchodennyi khlib» kursantiv UPA: zhytlove, materialno-tekhnichne, prodovolcheta medychne zabezpechennia starshynskykh ta pidstarshynskykh shkil UPA (1943 - 1944) [The «daily bread» of UPA cadets: dwelling, material, victual and medical sustenance of master sergeants (starshyn) and staff sergeants (pidstarsshyn) schools of UPA] // Ukrainskyi vyzvolnyi rukh / Tsentr doslidzhen vyzvolnoho rukhu, Instytut ukrainoznavstva im. I. Krypiakevycha NAN Ukrainy. Lviv: Kolo, 2004. Zbirnyk 3: Do 75-littia Orhanizatsii Ukrainskykh Natsionalistiv. S. 246-259. [in Ukrainian].

Patryliak, 2004b - Patryliak I. Starshynski y pidstarshynski shkoly UPA v 1943 - 1944 rr. [Master sergeants (starshyns'ki) and staff sergeants (pidstarsshyns'ki) schools of UPA in $1943-1944$ ] // Vyzvolnyi shliakh. 2004. Kn. 4 (673). S. 92-106. [in Ukrainian].

Remeslo povstantsia, 2007 - Remeslo povstantsia. Zbirnyk prats pidpolkovnyka UPA Stepana Frasuliaka«Khmelia» [The Insurgent's Craft: A collection of works of UPA lieutenant-colonel Stepan Frasuliak-«Khmil'»]/ red. i uporiad. R. Zabilyi. Lviv: Tsentr doslidzhen vyzvolnoho rukhu, 2007. 424 s. [in Ukrainian].

Rusnachenko, 2002 - Rusnachenko A. Narod zburenyi: Natsionalno-vyzvolnyi rukh v Ukraini y natsionalni rukhy oporu v Bilorusii, Lytvi, Latvii, Estonii u 1940 - 50-kh rokakh [The Revolted People: National liberation movement in Ukraine and national resistance movements in Belarus', Lithuania, Latvia, and Estonia in the 1940s 1950s]. Kyiv: Universytetske vydavnytstvo «Pulsary», 2002. - 519 s. [in Ukrainian].

Sodol, 1995 - Sodol P. Ukrainska Povstancha armiia [Ukrainian Insurgent Army] 1943 - 1949. Dovidnyk druhyi. Niu-York, 1995. 295 s. [in Ukrainian].

Fedorivskyi, 1962 - Fedorivskyi S. Notatky povstantsia [The Notes of an Insurgent]. Niu-York: Prometei, 1962. 207 s. [in Ukrainian].

Chyzhevskyi, 1948 - Chyzhevskyi V. Orhanizatsiia viiskovoi pratsi OUN [The OUN's organization of military work]. [b. m.; b. v.], 1948. - 132 s. [in Ukrainian].

Стаття надійшла до редакиії 21.01.2018 p. 